Article

\title{
Petrogenesis of Low Sr and High Yb A-Type Granitoids in the Xianghualing Sn Polymetallic Deposit, South China: Constrains from Geochronology and $\mathrm{Sr}-\mathrm{Nd}-\mathrm{Pb}-\mathrm{Hf}$ Isotopes
}

\author{
ChangHao Xiao *D, YuKe Shen and ChangShan Wei \\ Laboratory of Dynamic Diagenesis and Metallogenesis, Institute of Geomechanics, \\ Chinese Academy of Geological Sciences, Beijing 100081, China; shenyuke@geomech.ac.cn (Y.K.S.); \\ weichangshan@geomech.an.cn (C.S.W.) \\ * Correspondence: xiaochanghao1986@126.com or xiaochanghao@geomech.ac.cn; Tel.: +86-010-88815612
}

Received: 16 January 2019; Accepted: 11 March 2019; Published: 15 March 2019

check for updates

\begin{abstract}
The nature and origin of the early Yanshanian granitoids, widespread in the South China Block, shed light on their geodynamic setting; however, understanding their magmatism processes remains a challenge. In this paper, we present both major and trace elements of bulk rock, $\mathrm{Sr}-\mathrm{Nd}-\mathrm{Pb}$ isotopic geochemistry, and zircon $\mathrm{U}-\mathrm{Pb}-\mathrm{Hf}$ isotopes of the low $\mathrm{Sr}$ and high $\mathrm{Yb} \mathrm{A}_{2}$-type granites, which were investigated with the aim to further constrain their petrogenesis and tectonic implications. Zircon $\mathrm{U}-\mathrm{Pb}$ dating indicates that these granites were emplaced at ca. $153 \mathrm{Ma}$. The granites are characterized by high $\mathrm{SiO}_{2}(>74 \mathrm{wt} . \%)$ and low $\mathrm{Al}_{2} \mathrm{O}_{3}$ content (11.0 wt.\%-12.7 wt.\%; <13.9 wt.\%). They are enriched in large ion lithophile elements (LILEs) (e.g., Rb, Th, U, and K) and $\mathrm{Yb}$, but depleted in high field-strength elements (HFSEs) (e.g., Nb, Ta, $\mathrm{Zr}$ and $\mathrm{Hf}$ ), $\mathrm{Sr}, \mathrm{Ba} \mathrm{P}, \mathrm{Ti}$ and Eu concentrations. They exhibit enriched rare earth elements (REEs) with pronounced negative Eu anomalies. They have $\varepsilon_{\mathrm{Nd}}(\mathrm{t})$ values in a range from -6.5 to -9.3 , and a corresponding $\mathrm{T}_{\mathrm{DM}}$ model age of 1.5 to $1.7 \mathrm{Ga}$. They have a $\left({ }^{206} \mathrm{~Pb} /{ }^{204} \mathrm{~Pb}\right)_{\mathrm{t}}$ value ranging from 18.523 to 18.654 , a $\left({ }^{207} \mathrm{~Pb} /{ }^{204} \mathrm{~Pb}\right)$ t value varying from 15.762 to 15.797 , and a $\left({ }^{208} \mathrm{~Pb} /{ }^{204} \mathrm{~Pb}\right)_{\mathrm{t}}$ value ranging from 39.101 to 39.272 . The yield $\varepsilon_{\mathrm{Hf}}(\mathrm{t})$ ranges from -6.1 to -2.1 , with crustal model ages $\left(T_{\mathrm{DMC}}\right)$ of 1.3 to $1.6 \mathrm{Ga}$. These features indicate that the low $\mathrm{Sr}$ and high $\mathrm{Yb}$ weakly peraluminous $\mathrm{A}_{2}$-type granites were generated by overlying partial melting caused by the upwelling of the asthenosphere in an extensional tectonic setting. The rollback of the Paleo-Pacific Plate is the most plausible combined mechanism for the petrogenesis of $\mathrm{A}_{2}$-type granites, which contributed to the $\mathrm{Sn}-\mathrm{W}$ polymetallic mineralization along the Shi-Hang zone in South China.
\end{abstract}

Keywords: zircon $\mathrm{U}-\mathrm{Pb}$ geochronology; $\mathrm{Sr}-\mathrm{Nd}-\mathrm{Pb}-\mathrm{Hf}$ isotopes; low $\mathrm{Sr}$ and high $\mathrm{Yb} \mathrm{A}_{2}$-type granite; Xianghualing; South China

\section{Introduction}

The Mesozoic Age marks an important period in the geologic evolution of mainland South East Asia (Figure 1a) [1-4], during which extensive magmatism took place in the South China Block (SCB) parallel to the present-day coastline (Figure 1b). This magmatic zone was preliminarily named the "Shi-Hang zone" after Gilder et al. [4]. As a granitoid belt, it reveals the Nd-depleted mantle model ages $\left(\mathrm{T}_{\mathrm{DM}}=1.4 \pm 0.3 \mathrm{Ga}\right)$ and negative $\varepsilon_{\mathrm{Nd}}(\mathrm{t})$ values $(-4$ to -8$)$ in composition [5]. Such $\mathrm{Sn}-\mathrm{W}$ polymetallic metallogenic domains related to widespread granitoids in South China represents one of the largest tungsten-tin polymetallic ore provinces on Earth [6-15]. Previous studies demonstrated that these temporally and spatially associated intrusions are different in terms of petrography, and elemental and 
isotopic compositions, and argued for different petrogenesis and tectonic regimes, ranging from an extension [11], rift-related and convergent [5,16-19], or subduction-related models (Figure 1d) [20-24].

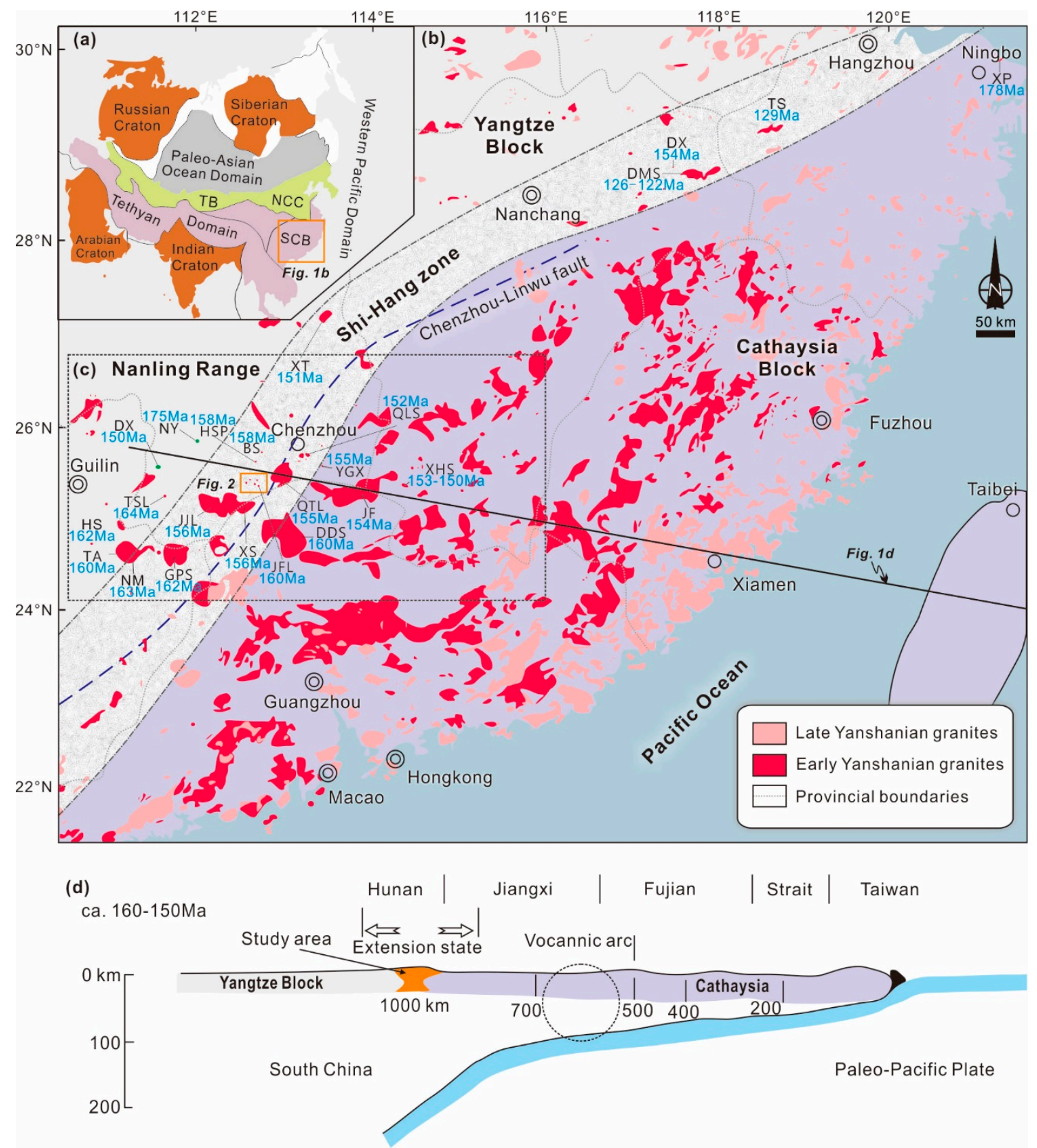

Figure 1. (a) Simplified tectonic map of Asia showing the framework of the joint area of the Paleo-Asian, Tethyan, and Pacific domains [4]. TB, Tibet Block; NCC, North China Block; SCB, South China Block. (b) Distribution of the Mesozoic intrusive rocks in South China [7,15,21,24,25]. The locations of the Shi-Hang zone and Nangling range are after $[19,26,27]$. (c) Sketch map of the Nanling Range [13]. (d) Simplified map showing the Late Jurassic subduction in Southeast China [28]. NM, Niumiao granodiorite [29]; TA, Tong'an monzonite [29]; HS, Huashan granite [30,31]; GPS, Guposhan granite [30,31]; TSL, Tongshanling granodiorite [19,32]; JJL, Jinjiling granite [19,33]; XS, Xishan granite [33]; DDS, Dadongshan granite [34]. JFL, Jianfengling (our no published data); DX, Daoxian basalt [19,35]; NY, Ningyuan basalt [19,35]; QTL, Qitianling granite [36]; HSP, Huangshaping granite [37]; BS, Baoshan granodiorite [32,38]; JF, Jiufeng granite [39,40]; QLS, Qianlishan granite [41]; YGX, Yaogangxian granite [42]; XHS, Xihuashan granite [43,44]; XT, Xitian granite [15]; DMS, Damaoshan granite [45]; DX, Dexing granodiorite [46]; TS, Tongshan granite [45]; XP, Xiepu granite [24]. 
The Xianghualing Sn polymetallic deposit is situated at the boundary between the Paleo-Pacific and the Tethyan tectonic domains (Figure 1a). The Late Jurassic granites related to this deposit could provide constraints on the petrogenesis of Late Jurassic granite-related W-Sn mineralization and their tectonic settings. In this contribution, we present major and trace element geochemistry, $\mathrm{Sr}-\mathrm{Nd}-\mathrm{Pb}$ isotope data for these granites, and zircon $\mathrm{U}-\mathrm{Pb}$ dating and $\mathrm{Hf}$ isotopic evidence.

\section{Geological Background}

The Yangtze Block to the northwest and the Cathaysia Block to the southeast were amalgamated to form the South China Block during the Neoproterozoic Era (Figure 1b) [7,11]. Numerous granites are distributed in the Cathaysia Block and the Shi-Hong zone. The study area is located in the central part of Shi-Hang zone (Figure 1b). The NE-SW trending of the Chenzhou-Lingwu fault zone represents a regional fault in the study area (Figure 1b) $[25,47]$. The zone was originally formed at $970 \mathrm{Ma}$ [1] and reactivated during the Triassic and the Cretaceous Eras [25]. A number of granite plutons and associated Sn polymetallic mineralization were distributed along the Chenzhou-Lingwu fault belt to the west of Shi-Hong zone (Figure 1b). This Sn-metallogenic region, called the Nanling Range, is characterized by multiple and diverse mineral deposits ( $\mathrm{W}, \mathrm{Sn}, \mathrm{Cu}, \mathrm{Pb}-\mathrm{Zn}$, etc.) and the Jurassic-Cretaceous intrusions [13]. The granites include the Baoshan, Tongshanling, Niumiao, Yuanzhuding, Guposhan, Huashan, Xishan, Jinjiling, Qianlishan, and Qitianling plutons (Figure 1b). Ore deposits associated to this belt are: Shizhuyuan (W-Sn-Mo-Bi-F) [48], Furong (Sn) [6,49,50], Yaogangxian (W) [49], Xianghualing (Sn-W-Pb-Zn) [12,51], Huangshaping (Pb-Zn-W-Sn) [7,52], Baoshan (Cu-Pb-Zn-W) [38], and Yuanzhuding (Cu-Mo) [14]. Basaltic rocks also crop out near the Chenzhou-Lingwu fault, such as the Daoxian and Ningyuan basalts (Figure 1b) [19,35].

The Xianghualing Sn-polymetallic deposit is situated at the Midwestern point of the Nanling Range (Figure 1c). The Xinfeng mine is one of the most important mines in the Xianghualing deposit. The Xianghualing area is a tectono-magmatic dome (Figure 2a). The exposed basement comprises the Cambrian slate and metasandstone, sandstone and shale in the Middle Devonian Tiaomajian Formation, limestone and dolomitic limestone in the Middle Devonian Qiziqiao Formation, dolomitic limestone and sandstone in the Upper Devonian of the Shetianqiao Formation, and the Carboniferous carbonate and clastic rocks. The Qiziqiao Formation is the major ore bed, and the Laiziling and Jianfengling are the two largest granites which intruded into the Cambrian and Devonian Eras, respectively. The Xianghualing Sn polymetallic deposit is a typical skarn deposit related Laiziling Pluton [12]. Skarn-type ore bodies and vein-like bodies formed in the contact zone of the granites.

\section{Sampling and Analytical Methods}

The granite samples in this study included ZK65-1, ZK65-2, ZK65-3 and ZK57-1 and were collected from drill cores ZK65 and ZK57, one of the deepest holes of Laiziling pluton prior to 2015, in the Xinfeng mine, Xianghualing deposit (Figure 2b). The sequence from the granite to the country rocks is as follows: granite $\rightarrow$ altered sandstone $\rightarrow$ skarn $\rightarrow$ Sn polymetallic ores in the drill cores ZK65, or, alternatively, granite $\rightarrow$ skarn $\rightarrow$ tungsten-bearing quartz veins $\rightarrow$ ore-bearing marble $\rightarrow$ fracture in drill core ZK57 (Figure $2 b$ ). The pluton in the mine connects with the Laiziling pluton that exposes on the surface. Three granite samples collected from the drill core ZK65 are mainly composed of fine to medium grained porphyritic biotite monzonitic granites with a porphyritic texture. They contain 30-35\% rounded, variably resorbed quartz phenocrysts of 1-8 $\mathrm{mm}$ in diameter, $10-15 \%$ euhedral-subhedral K-feldspar phenocrysts of 5-10 mm in length, about 5-10\% equant and tabular plagioclase phenocrysts of $0.5-2 \mathrm{~mm}$ in length, biotite (3-8\%), and minor to trace amounts of hornblende. (Figure 3a,b). Some K-feldspar phenocrysts have partially experienced sericitization. Sample ZK57-1 is two-mica monzonitic granite with small phenocrysts and finer-grained quartz (30-35\%), K-feldspar (10-15\%), plagioclase $(10-15 \%)$, biotite (3-8\%), and muscovite (3-8\%) (Figure 3c,d). Accessory minerals are composed of zircon with minor apatite. 
Details of analytical methods, namely whole-rock major and trace element compositions, $\mathrm{Sr}-\mathrm{Nd}-\mathrm{Pb}$ isotopes, and zircon $\mathrm{U}-\mathrm{Pb}$ and $\mathrm{Lu}-\mathrm{Hf}$ isotope analyses are presented in the Supplementary material.
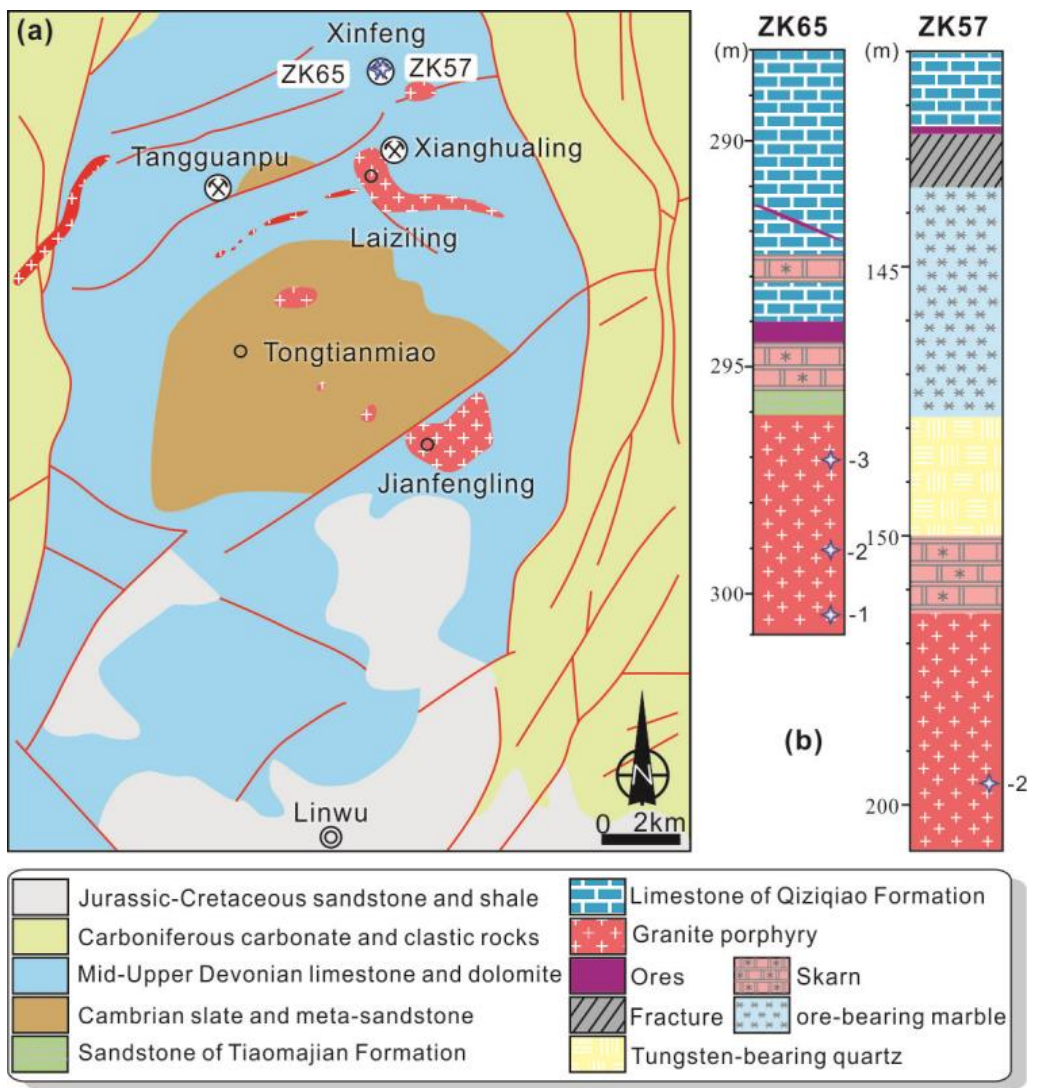

Figure 2. (a) The simplified geological map of the Xianghualing Sn-polymetallic deposit, South China $[12,53]$. (b) Drill core profile showing the sample locations.
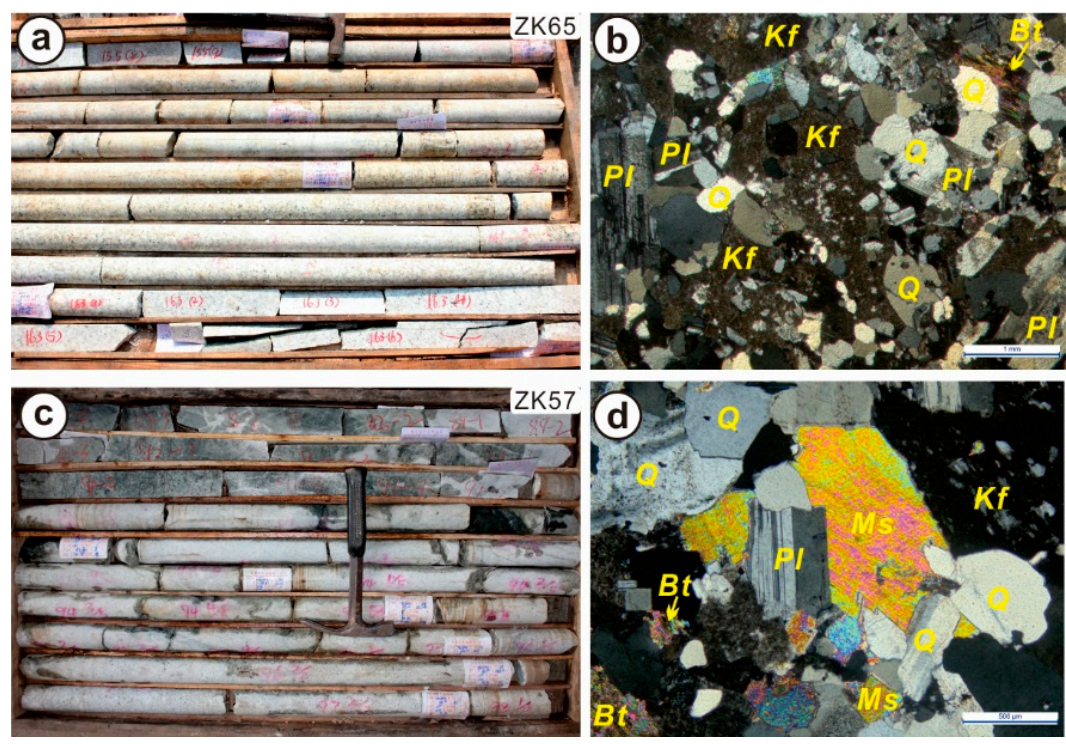

Figure 3. Drill cores and micrographics of ZK65 and ZK57 from the Xinfeng mine, Xianghualing area, South China. (a,b) Biotite monzonitic granites from ZK65. (c,d) Two-mica monzonitic granite from ZK57. Q, quartz; Kf, feldspar; Bt, biotite; Ms, muscovite; Pl, plagioclase. 


\section{Results}

\subsection{Whole-Rock Geochemistry}

\subsubsection{Major and Trace Elements}

The analytical results of the four granite samples are presented in Table S1. These granites have characteristics of high $\mathrm{SiO}_{2}$ content (74.1 wt.\%-78.0 wt.\%) (Figure 4a), similar to that of the Jianfengling granites (73.6 wt.\%-75.2 wt.\%) [53], and Qitianling granites (65.9 wt.\%-75.7 wt.\%) in this region [54,55]. They are enriched in alkalis, with the $\mathrm{K}_{2} \mathrm{O}+\mathrm{Na}_{2} \mathrm{O}$ contents ranging from $7.2 \mathrm{wt} . \%$ to 9.2 wt.\% (average $8.3 \mathrm{wt} . \%$ ), and $\mathrm{K}_{2} \mathrm{O} / \mathrm{Na}_{2} \mathrm{O}$ ratios higher than 1 . The samples are plotted in the high $\mathrm{K}$ calc-alkaline field in the $\mathrm{Na}_{2} \mathrm{O}+\mathrm{K}_{2} \mathrm{O}-\mathrm{CaO}$ vs. $\mathrm{SiO}_{2}$ diagram (Figure 4a). They exhibit low $\mathrm{Al}_{2} \mathrm{O}_{3}$ contents (11.0 wt. \% to 12.7 wt.\%), and A/CNK ratios (1.0-1.1) lower than 1.1, indicating their weak peraluminous affinity in the $\mathrm{A} / \mathrm{NK}$ vs. A/CNK diagram (Figure 4b). They have low $\mathrm{Fe}_{2} \mathrm{O}_{3}(0.1$ wt. $\%-0.5$ wt.\%), $\mathrm{MgO}(0.1$ wt. $\%$ ), $\mathrm{CaO}\left(0.6\right.$ wt. $\%-0.8$ wt.\%), $\mathrm{TiO}_{2}\left(0.1\right.$ wt.\%), and $\mathrm{P}_{2} \mathrm{O}_{5}$ contents.
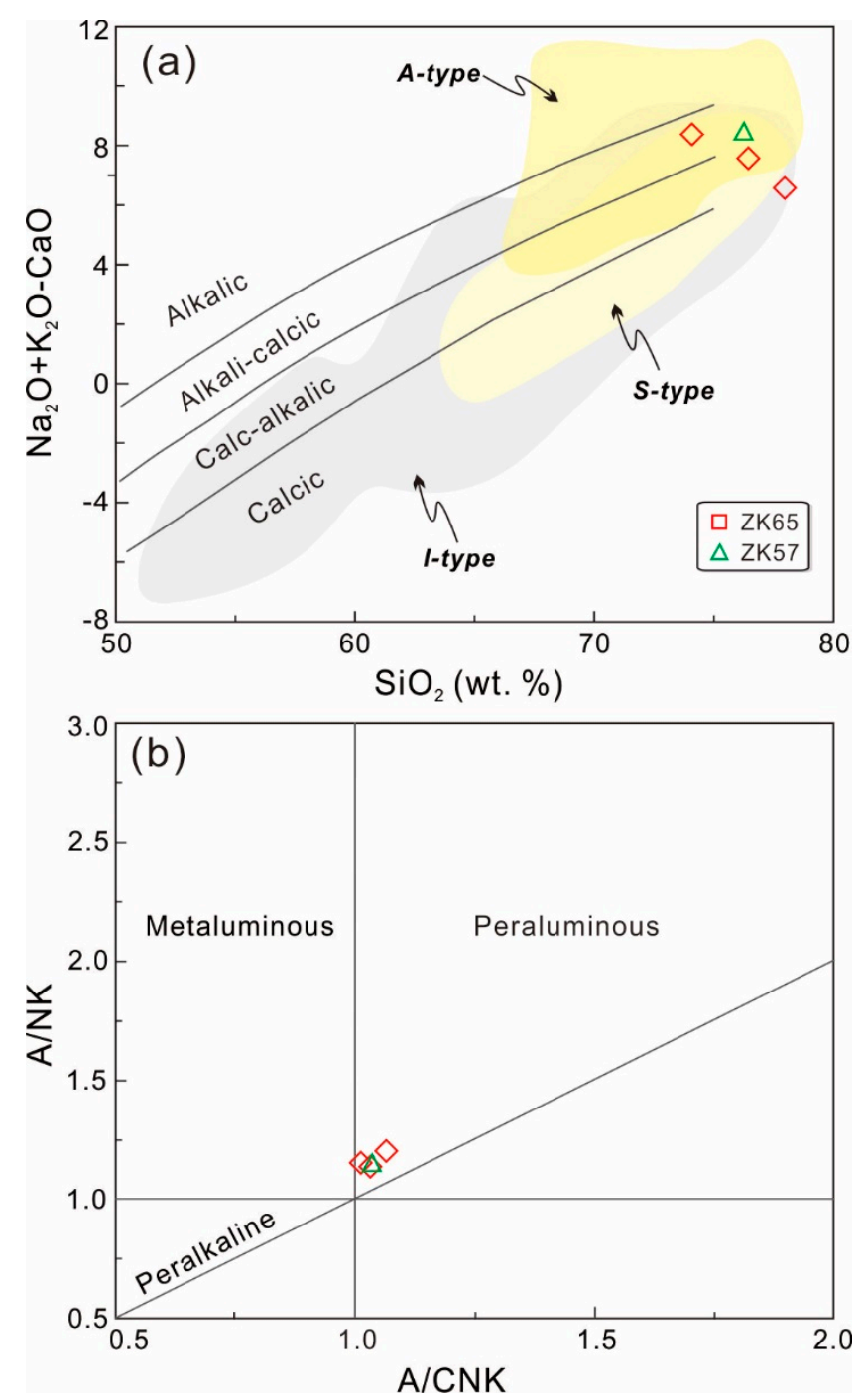

Figure 4. (a) Diagram of $\mathrm{SiO}_{2}$ vs. $\mathrm{Na}_{2} \mathrm{O}+\mathrm{K}_{2} \mathrm{O}-\mathrm{CaO}$ [56]; (b) Diagram of $\mathrm{Al} /(\mathrm{K}+\mathrm{Na})$ vs. $\mathrm{Al} /(\mathrm{Ca}+\mathrm{K}+\mathrm{Na})$ [57].

A primitive mantle-normalized trace element diagram and chondrite-normalized rare earth element (REE) patterns for the four granite samples are illustrated in Figure 5a,b, respectively. All samples have low $\mathrm{Sr}$ (3.6-7.3 ppm) and $\mathrm{Nb}$ (0.3-2.5 ppm, except ZK65-1) contents and extremely high Rb (1606-2351 ppm) and Yb (7.9-14 ppm) contents. They are enriched in large-ion lithophile 
elements (LILEs) (e.g., Rb, Th, U, and K) and depleted in high field strength elements (HFSEs) (e.g., $\mathrm{Nb}, \mathrm{Ta}, \mathrm{Zr}$ and $\mathrm{Hf}$ ), $\mathrm{Sr}$, and $\mathrm{Ba}$ (Figure $5 \mathrm{a}$ ). The total contents of $\mathrm{Zr}, \mathrm{Nb}, \mathrm{Ce}, \mathrm{Y}$ of four samples range from 430 to $646 \mathrm{ppm}$ (Figure 6). The granites exhibit enriched REEs (except Eu) with a total REE ranging from 233 to $312 \mathrm{ppm}$. They are characterized by a slight enrichment of light REE (LREE) $\left((\mathrm{La} / \mathrm{Yb})_{\mathrm{N}}=1.8-5.0\right)$ and flat heavy REE (HREE) with pronounced negative Eu anomalies $(\delta \mathrm{Eu}=0.02)$ (Figure 5b). The differentiation indexes (DI) of these samples are 93.7-94.58 (Table S1).
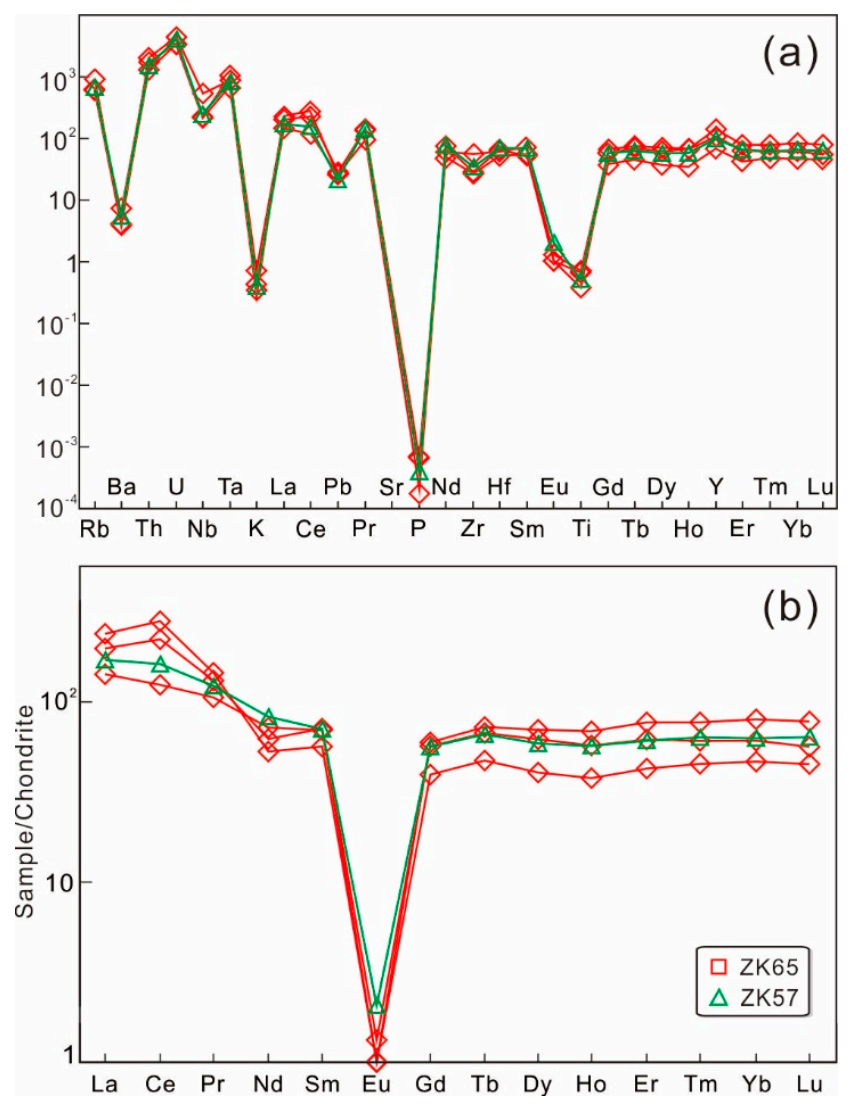

Figure 5. (a) Primitive mantle-normalized trace element spider diagram; (b) Chondrite-normalized REE patterns for the granites from the Xinfeng mine, Xianghualing area, South China. Normalized values for primitive mantle and chondrite are from Sun and McDonough [58].
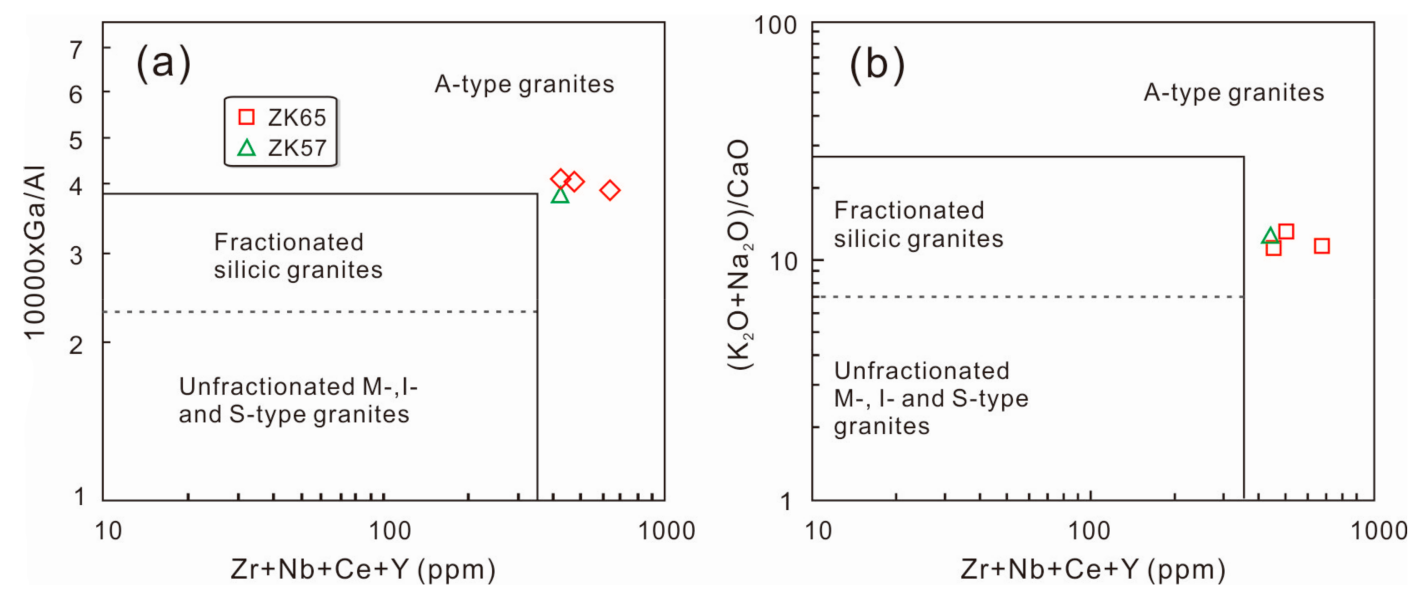

Figure 6. (a) $10,000 \times \mathrm{Ga} / \mathrm{Al}$ and; (b) $\left(\mathrm{K}_{2} \mathrm{O}+\mathrm{Na}_{2} \mathrm{O}\right) / \mathrm{CaO}$ vs. $\mathrm{Zr}+\mathrm{Nb}+\mathrm{Ce}+\mathrm{Y}(\mathrm{ppm})$ diagrams showing that the Jurassic low $\mathrm{Sr}$ and high $\mathrm{Yb}$ granites are A-type granites [59]. 


\subsection{2. $\mathrm{Sr}-\mathrm{Nd}-\mathrm{Pb}$ Isotopic Compositions}

The $\mathrm{Sr}-\mathrm{Nd}-\mathrm{Pb}$ isotopic composition data for the granites are presented in Table S2. Initial values of $\left({ }^{206} \mathrm{~Pb} /{ }^{204} \mathrm{~Pb}\right)_{\mathrm{t}},\left({ }^{207} \mathrm{~Pb} /{ }^{204} \mathrm{~Pb}\right)_{\mathrm{t}}$, and $\left({ }^{208} \mathrm{~Pb} /{ }^{204} \mathrm{~Pb}\right)_{\mathrm{t}}$ are calculated using zircon ages of $153 \mathrm{Ma}$.

The granites have an extremely high ${ }^{87} \mathrm{Sr} /{ }^{86} \mathrm{Sr}$ ratio (up to 1.89 ), which may be due to their extreme $\mathrm{Sr}$ (also $\mathrm{Eu}$ and $\mathrm{Ba}$ ) depletion, and thus a very high $\mathrm{Rb} / \mathrm{Sr}$ ratio. Previous studies pointed that the initial of $\mathrm{Sr}$ isotope is unreliable of high $\mathrm{Rb}$ granite [60]. We therefore do not discuss the initial ratio of $\mathrm{Sr}$ isotopes on the petrogenesis of the Xianghualiang granites. They have $\varepsilon_{\mathrm{Nd}}(\mathrm{t})$ values ranging from -9.3 to -6.5 and $\left({ }^{143} \mathrm{Nd} /{ }^{144} \mathrm{Nd}\right)_{i}$ from 0.511963 to 0.512107 , corresponding to depleted mantle model ages $\left(\mathrm{T}_{\mathrm{DM} 2}-\mathrm{Nd}\right)$ of $1471-1702 \mathrm{Ma}$. The plots of $\varepsilon_{\mathrm{Nd}}(\mathrm{t}) \mathrm{vs} .{ }^{206} \mathrm{~Pb} /{ }^{238} \mathrm{U}$ age is exhibited in Figure $7 \mathrm{a}$.

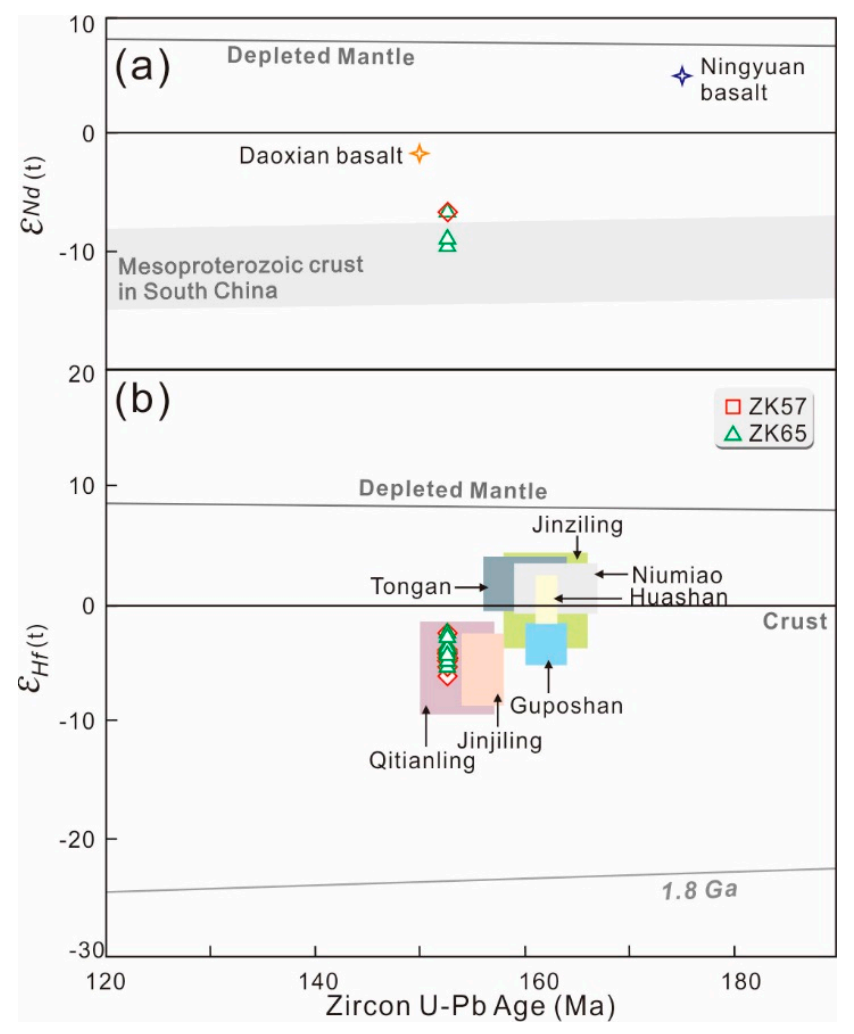

Figure 7. (a) $\varepsilon_{\mathrm{Nd}}(\mathrm{t})$-age diagram and (b) $\varepsilon_{\mathrm{Hf}}(\mathrm{t})$-age diagram for zircons from Xianghualing area. The data of zircon $\mathrm{U}-\mathrm{Pb}$ age, $\varepsilon_{\mathrm{Nd}}(\mathrm{t})$ and $\varepsilon_{\mathrm{Hf}}(\mathrm{t})$ are from $[7,15,21,24-45]$.

Four samples are characterized by high radiogenic $\mathrm{Pb}$ isotopic composition, with present-day rock ${ }^{206} \mathrm{~Pb} /{ }^{204} \mathrm{~Pb},{ }^{207} \mathrm{~Pb} /{ }^{204} \mathrm{~Pb}$, and ${ }^{208} \mathrm{~Pb} /{ }^{204} \mathrm{~Pb}$ ratios of 19.624 to $19.791,15.816$ to 15.847 , and 39.478 to 39.795 , and their corresponding initial ratios are 18.523 to $18.654,15.762$ to 15.797 , and 39.101 to 39.272 , respectively.

\subsection{Zircon $\mathrm{U}-\mathrm{Pb}$ Ages}

Most zircon grains separated from four granite samples are euhedral and prismatic with aspect ratios of 1:1-1:2 and lengths of 50-150 $\mu \mathrm{m}$. They are transparent and light yellow under an optical microscope. Ubiquitous simple internal oscillatory zoning and little inherited cores are observed by Cathodoluminescence (CL) images (Figure 8). Such characteristics indicate they are magmatic zircon in origin [61]. A few zircon crystals exhibit complex secular zonings (Figure 8).

LA-ICP-MS zircon U-Pb isotopic data for these granitoids are shown in Table S3. The zircon $\mathrm{U}-\mathrm{Pb}$ concordia and weighted mean diagrams are illustrated in Figure 9. These zircons have varied $\mathrm{U}$ (154-6771 ppm) and Th (70-4505 ppm) contents, with Th/U ratios ranging from 0.3 to 0.8 (Table S3), indicating that they are magmatic in origin [62]. Thirteen analyses fall on the Concordia in a single 
group from the sample ZK57, yielding a Concordia age of $152.8 \pm 0.6 \mathrm{Ma}$ (MSWD $=0.2, n=13$ ). The remaining three analyses have a ${ }^{206} \mathrm{~Pb} /{ }^{238} \mathrm{U}$ age of $148.3 \pm 1.5 \mathrm{Ma}$ and 147.1 $\pm 1.8 \mathrm{Ma}$ (Figure 9a). Fifteen spot analyses of zircons from sample ZK65 yield a single ${ }^{206} \mathrm{~Pb} /{ }^{238} \mathrm{U}$ age population of 105-156 Ma with Concordia age of 152.7 $\pm 2.0 \mathrm{Ma}(\mathrm{MSWD}=2.9, n=9)$ (Figure 9b and Table S3). The two Concordia ages may represent the crystallization age of the granites.

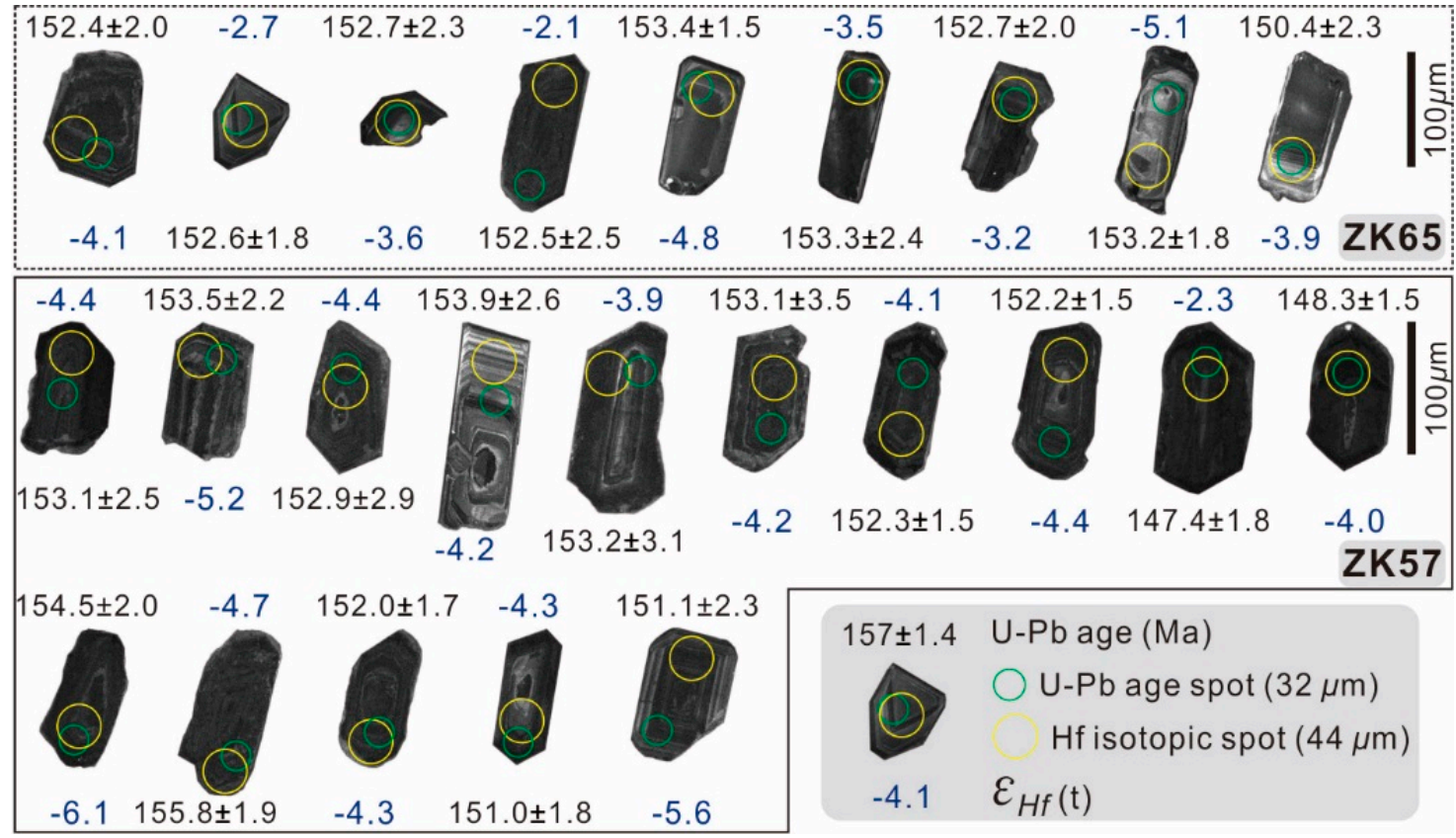

Figure 8. CL electron micrographs of representative zircons separated from the drill cores of ZK65 and ZK57 from the Xinfeng mine, Xianghualing area, South China. Spots are tested by in situ U-Pb age and Hf isotope.
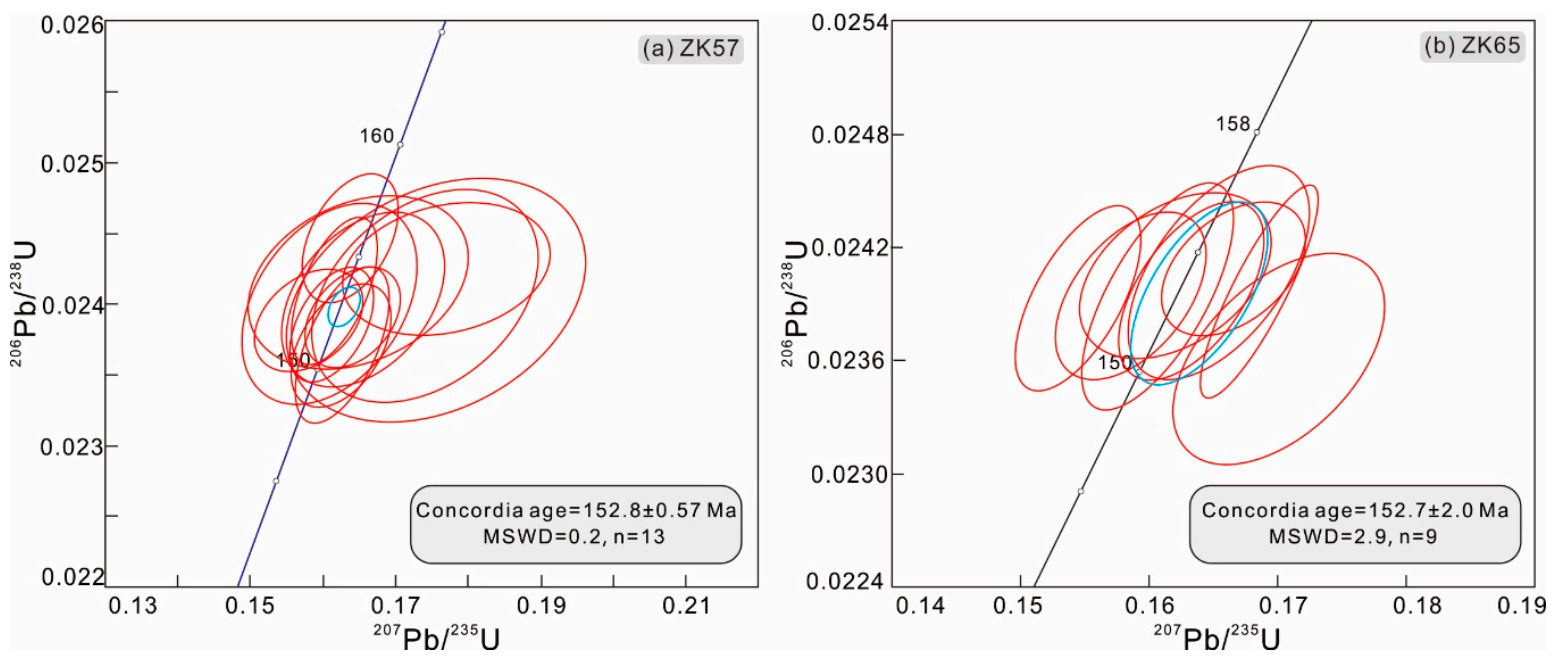

Figure 9. LA-CP-MS zircon U-Pb Concordia diagrams for the drill cores of ZK57 (a) and ZK65 (b) from the Xinfeng mine, Xianghualing area, South China.

\subsection{Zircon Hf Isotopes}

The Lu-Hf isotopic compositions of zircon crystals separated from the two granite samples from the Xianghualing area in South China are listed in Table S4. The plots of $\varepsilon_{\mathrm{Hf}}(\mathrm{t}) \mathrm{vs} .{ }^{206} \mathrm{~Pb} /{ }^{238} \mathrm{U}$ age is illustrated in Figure $7 \mathrm{~b}$. 
The zircons have ${ }^{176} \mathrm{Lu} /{ }^{177} \mathrm{Hf}$ ratios from 0.000776 to 0.003445 and ${ }^{176} \mathrm{Hf} /{ }^{177} \mathrm{Hf}$ ratios from 0.282514 to 0.282628 (Table S4). Most of ${ }^{176} \mathrm{Lu} /{ }^{177} \mathrm{Hf}$ ratios of zircon from ZK57 are below 0.002 , and therefore the accumulation of radiogenic Hf after the formation of zircons can be ignored. ${ }^{176} \mathrm{Lu} /{ }^{177} \mathrm{Hf}$ ratios of zircon from ZK65 are a little large than 0.002 except for two analyses (ZK65-1, ZK65-5), indicating a minor radiogenic production of ${ }^{176} \mathrm{Hf}$. The $\varepsilon_{\mathrm{Hf}}(\mathrm{t})$ values for analyses of zircon from the samples ZK57 and ZK65 vary from -6.1 to -2.1 (Figure $7 \mathrm{~b}$ ) and yield crustal model ages ( $\mathrm{T}_{\mathrm{DMC}}$ ) for the zircon crystals from the samples that have a spectrum from $1336 \mathrm{Ma}$ to $1588 \mathrm{Ma}$. The $\varepsilon_{\mathrm{Hf}}(\mathrm{t})$ values of ZK57 are close and smaller than those of ZK56 (Table S4).

\section{Discussion}

\subsection{Origin of Granitic Rocks: An A2-Type Affinity}

The later Jurassic granitic rocks from the Xianghualing area exhibit features of high silica (74.1-78.0 wt.\%) and weak peraluminosity (A/CNK ratios $=1.0-1.1)$. They have high $\mathrm{K}_{2} \mathrm{O}$ contents $\left(\mathrm{K}_{2} \mathrm{O} / \mathrm{Na}_{2} \mathrm{O}\right.$ ratios $\left.=1.4-4.3\right)$ and low $\mathrm{CaO}, \mathrm{Ba}$, and $\mathrm{Sr}$ contents. They are enriched in $\mathrm{Nb}$, and $\mathrm{Ta}$, and HFSE contents $(\mathrm{Zr}+\mathrm{Nb}+\mathrm{Ce}+\mathrm{Y}=430-646 \mathrm{ppm})$ (Figure 6b). They have HFSE contents higher than those of A-type granites (350 ppm) [59]. Chondrite-normalized REE plots show relatively flat patterns with large negative Eu anomalies. These features are consistent with those of A-type granites rather than $\mathrm{S}$ and I-types [63-66]. They are characterized by extremely low $\mathrm{P}_{2} \mathrm{O}_{5}$ abundances and limited phosphate minerals, compared with S-type granites.

Strontium contents have been acknowledged as a discriminating parameter to classify granites of A-type granites [63]. The granitic rocks from the Xianghualing area have extremely lower Sr contents $(<10 \mathrm{ppm})$ than typical calc-alkaline I-type granites. Zhang et al. demonstrated that A-type granites in South China are characterized by low $\mathrm{Sr}$ and high $\mathrm{Yb}$, using a Sr-Yb diagram with obvious V-type REE patterns [67]. The much lower Sr contents therefore suggest that the granites from the Xianghualing area belong to A-type granites. Biotite and hornblendes commonly exist as interstitial clots or grains (Figure 10a). Moreover, micrographic intergrowths of quartz and myrmekite usually develop in or around the alkali feldspar (Figure 10). These features are consistent with those of typical A-type granites $[59,68]$. In the $10,000 \times \mathrm{Ga} / \mathrm{Al}$ and $\left(\mathrm{K}_{2} \mathrm{O}+\mathrm{Na}_{2} \mathrm{O}\right) / \mathrm{CaO}$ vs. $\mathrm{Zr}+\mathrm{Nb}+\mathrm{Ce}+\mathrm{Y}(\mathrm{ppm})$ diagrams, as well as the $\mathrm{SiO}_{2}$ vs. $\mathrm{Na}_{2} \mathrm{O}+\mathrm{K}_{2} \mathrm{O}-\mathrm{CaO}$ diagrams, they plot within A-type granites field (Figures $4 \mathrm{a}$ and $6 \mathrm{a}, \mathrm{b})$. All the samples fall into the $\mathrm{A}_{2}$-type granites field in the plot of $\mathrm{Ce} / \mathrm{Nb}$ versus $\mathrm{Y} / \mathrm{Nb}$ and $\mathrm{Nb}-\mathrm{Y}-3 \mathrm{Ga}$ discrimination diagrams (Figure 11a,b), and this is also evident in the plot of the R1-R2 diagram [69] (Figure 11c).
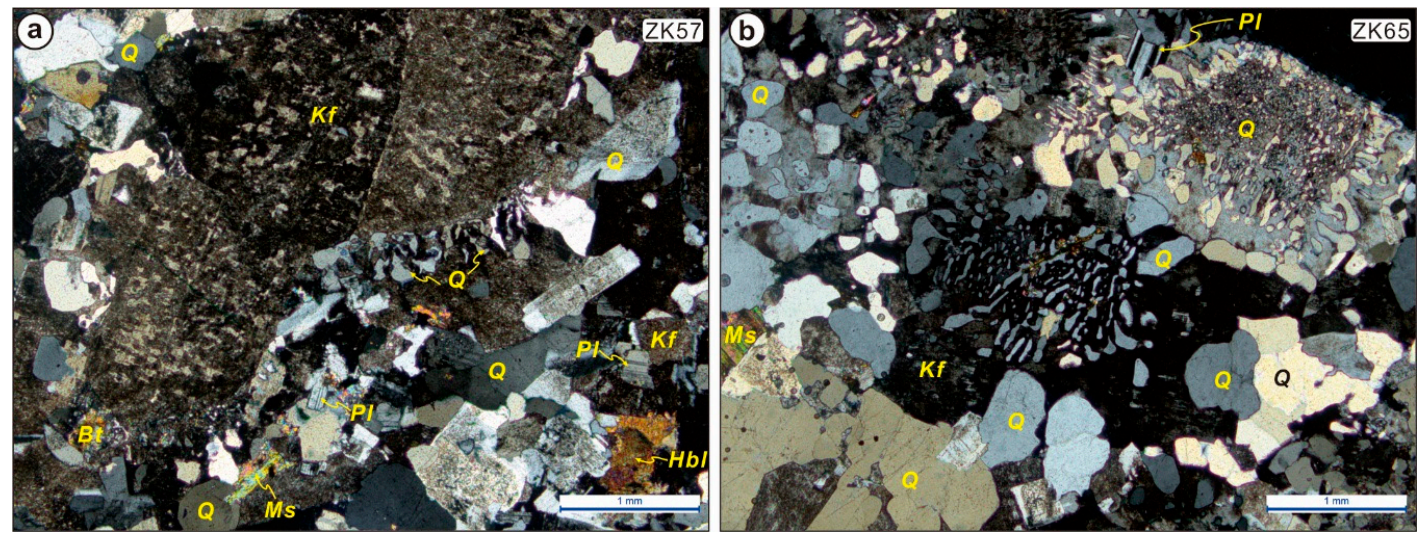

Figure 10. (a) Micrographic intergrowths of quartz and myrmekite develop around the alkali feldspar from the ZK57; (b) The alkali feldspar was replaced by the quartz from the ZK65. Q-quartz, Kf-feldspar, Bt-biotite, Ms-muscovite, Pl-plagioclase; Hbl-hornblende. 

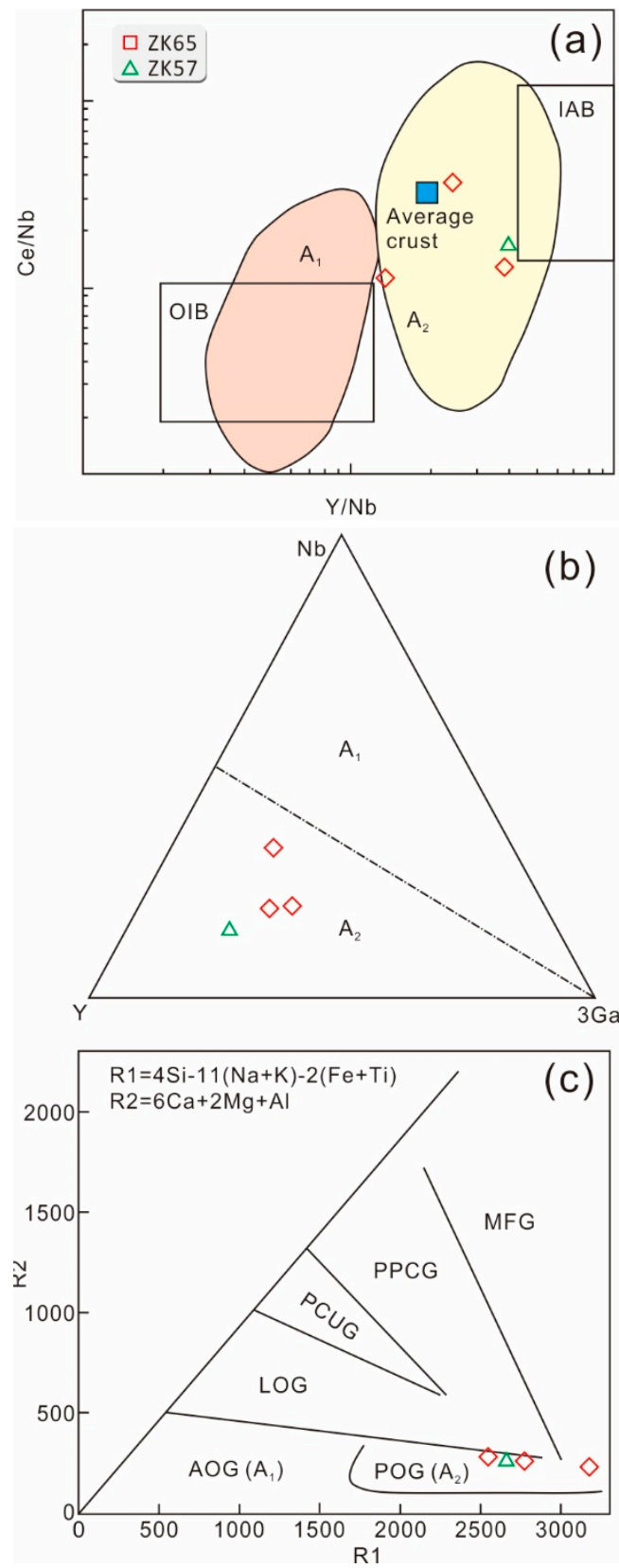

Figure 11. (a) Plots of $\mathrm{Ce} / \mathrm{Nb}$ vs. $\mathrm{Y} / \mathrm{Nb}$ [70]; (b) Nb-Y-3Ga [70]; (c) the diagrams of Ta-Yb, "R1-R2" [69] for the Xianghualing granites. OIB, ocean island basalt; IAB, island arc basalt; MFG, mantle-fractionated granite; PPG, pre-plate collision granitoids; PUCG, post-collision uplift granitoids; LOG, late-orogenic granitoids; AOG, anorogenic granitoids; POG, post-collision granitoids.

\subsection{Petrogenesis}

The petrogenesis of A-type granites are still debated, and several petrogenetic schemes have been proposed [64,69-75]. The Xianghualing granites have low A/CNK values and no aluminous minerals, which is inconsistent with the metasedimentary-melting petrogenetic model [76]. The rocks exhibit flat heavy REE patterns and high Y contents (116-235 ppm) indicating that garnet was absent from the source reservoir during the partial melting process [73]. The rocks from Xianghualing show weakly peraluminous affinities, which are consistent with crustal magmas produced by partial melting and heated by the underplating of mantle-derived magma [77-79]. This is evident by the obviously different $\mathrm{Nd}-\mathrm{Hf}$ isotopic compositions between the samples and the coeval mafic rocks (Figures $7 \mathrm{a}$ 
and 12). Figures $7 \mathrm{a}$ and 12 also indicate that the extensive fractional crystallization from coeval mafic magmas for the origin of the $\mathrm{A}_{2}$-type granites can be ruled out.

The granites exclusively display negative zircon $\varepsilon_{\mathrm{Hf}}(\mathrm{t})$ values, ranging from -6.1 to -2.1 , with a corresponding crustal model age of 1.34 to $1.59 \mathrm{Ga}$ (Figure $7 \mathrm{~b}$ and Table S4). The whole rock Nd model age is $1.47 \mathrm{Ga}-1.70 \mathrm{Ga}$, consistent with the Hf model age. These suggest that the sources of materials had a relatively simple recycling process. The relatively young $\mathrm{Nd}$ model ages are a little younger than or similar to that of Mesoproterozoic sediments in South China Block (Figure 7a; $\mathrm{T}_{\mathrm{DM}}=1.8 \mathrm{Ga}$ ) [80]. This indicates a dominated ancient crust material in South China contributed during the magmatic process. The $\varepsilon_{\mathrm{Hf}}(\mathrm{t})$ vs. $\varepsilon_{\mathrm{Nd}}(\mathrm{t})$ plots display that the range of granites from Xianghualiang area is similar to the Shi-Hang zone [29-31,33,54,81,82], and the range falls into the field of superimposed areas between global lower crust and global sediments (Figure 12). It suggests the lower crust and/or sediments could be involved during the magmatic process. The lead isotopic values of the four samples from the Xianghualing area display limited variations near the upper crust curve in Figure 13, which is similar to the crust materials in the Shi-Hang zone and the western Pacific subducted sediments at trenches, suggesting that the nature source rocks could be dominated by crustal materials [83]. The high radiogenic lead isotopic compositions in the granites from the Xianghualing area support that the magmas for these granites are predominately derived from crustal materials.

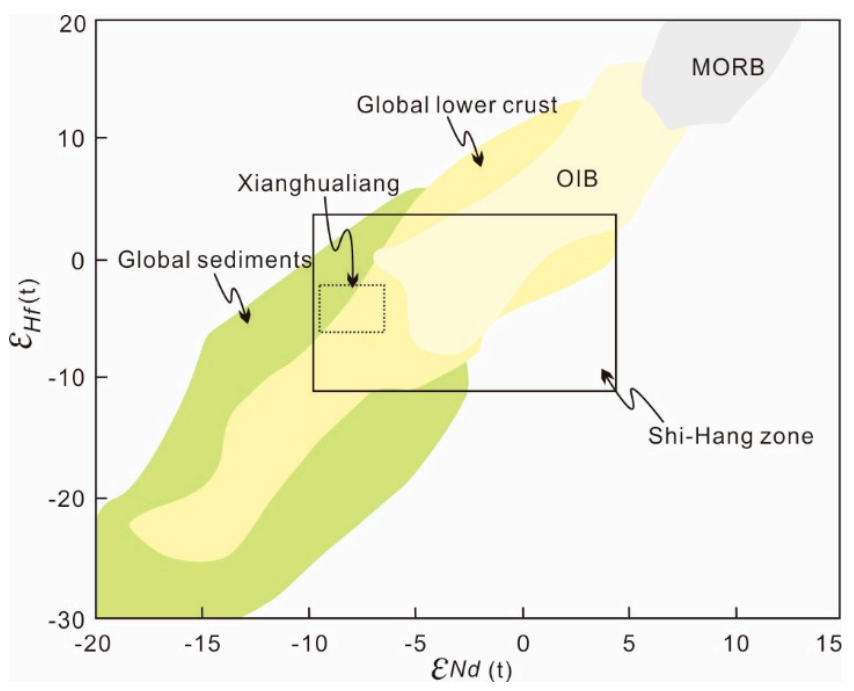

Figure 12. $\varepsilon_{\mathrm{Nd}}(\mathrm{t})$ vs. $\varepsilon_{\mathrm{Hf}}(\mathrm{t})$ for the granites from Xianghualing area South China. Plots of $\varepsilon_{\mathrm{Nd}}(\mathrm{t})$ vs. $\varepsilon_{\mathrm{Hf}}(\mathrm{t})$ fall into the quadrangle. The average values concentrate in the dotted quadrangle. The data of $\varepsilon_{\mathrm{Nd}}(\mathrm{t})$ and $\varepsilon_{\mathrm{Hf}}(\mathrm{t})$ are from $[29-31,33,54,81,82]$. MORB, mid-ocean ridge basalt.

As shown in Table $\mathrm{S} 1$ and Figure $11 \mathrm{a}$, the low $\mathrm{Gd} / \mathrm{Yb}$ ratios and fairly high $\mathrm{Y} / \mathrm{Nb}$ ratios indicate that the granites formed in the extensional setting $[63,84-86]$. This is consistent with the support formative processes of $\mathrm{A}_{2}$-type granites, which are considered to crystallize at a high temperature $[72,74,75]$. The presence of micrographic texture in these $\mathrm{A}_{2}$-type granites is also indicative of a high-level emplacement and provides evidence for an extensional regime (Figure 10) [69,72] and that the magmas formed near the earth surface [68]. A normal geothermal gradient, however, cannot produce high-temperature A-type granites by crustal melting; therefore, an exotic heat source from mantle is a prerequisite. In conclusion, a reasonable explanation for the granites with the signatures of high temperature from the Xianghualing area was generated by partial melting of the crustal materials with minor subducted sediments, and further caused by upwelling of asthenosphere in an extension tectonic setting. The presence of coeval basaltic rocks near the Chenzhou-Lingwu fault supports that a lithospheric extension event could occur during the Early Jurassic Era, such as the Ningyuan alkaline basalts (175 Ma) and the Daoxian basalt (150 Ma) [87-89]. These upwelling mantle materials might provide heat energy for the melting of the crustal materials and subducted sediments. 


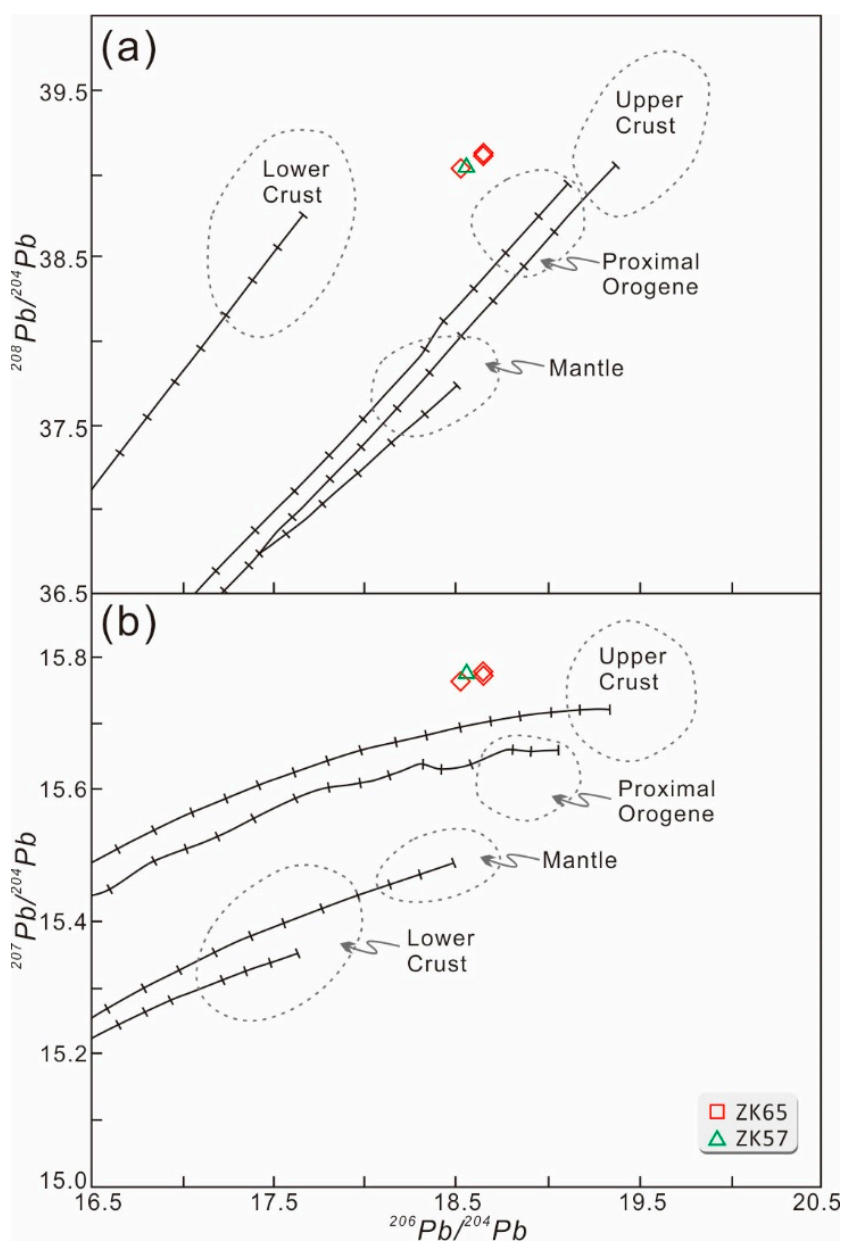

Figure 13. $\mathrm{Pb}$ isotopic composition of the Jurassic weak peraluminous granites are A-type granites. (a) ${ }^{206} \mathrm{~Pb} /{ }^{204} \mathrm{~Pb}$ vs. ${ }^{208} \mathrm{~Pb} /{ }^{204} \mathrm{~Pb}$ diagram of samples; (b) ${ }^{206} \mathrm{~Pb} /{ }^{204} \mathrm{~Pb}$ vs. ${ }^{207} \mathrm{~Pb} /{ }^{204} \mathrm{~Pb}$ diagram of samples [83].

\subsection{Tectonic Implications}

The $\mathrm{A}_{2}$-type granite has been generally considered to be derived from the crust in the subduction zone or the continent-continent collision zone [15]. Various models for the formation of A-type granites in South China are proposed in terms of tectonic setting, and these have been correlated with the subduction of the Pale-Pacific Plate for the petrogenesis of the late Mesozoic magma zone $[15,24,28,90-94]$. Zircon U-Pb dating on granites in the Xianghualing area demonstrate that the granites were emplaced at $153 \mathrm{Ma}$. The age is close to those of A-types granites in the Shi-Hang zone, such as Xihuashan (150-153 Ma, [43,44]), Jiufeng (154 $\pm 1 \mathrm{Ma},[39,40])$, Xitian (152 $\pm 1 \mathrm{Ma},[15])$, Qianlishan (152 $\pm 2 \mathrm{Ma}$, [18]), Qitianling (155 $\pm 1 \mathrm{Ma}$, [36]), Xishan (156 $\pm 2 \mathrm{Ma}$, [33]), Jinjiling $(156 \pm 2 \mathrm{Ma},[19,33])$, Huashan $(162 \pm 2 \mathrm{Ma},[30,31])$, and Guposhan $(162 \pm 2 \mathrm{Ma},[19,32])$. These granites formed a north east trending A-type granite belt in the Shi-Hang zone.

We thus propose that these $\mathrm{A}_{2}$-type granites could be formed in an extensional setting (Figure 1d). The Paleo-Pacific Plate subducted underneath the SE China Block at a very low angle, beginning in the Late Triassic Era and reaching southern Hunan at ca. $174 \mathrm{Ma}$ (Figure 14a) [24,94,95]. The low angle subduction could have caused crustal thickening in the coastal area. Due to the temperature and pressure increases, the ferroan (A-type) granitoids were emplaced in the orogenic thermal relaxation regime [24]. From ca. 174 to $164 \mathrm{Ma}$, the slab dip angle increased and subsequently caused the subducting slab to dehydrate and release fluids. The slab-released fluids triggered partial melting of mantle wedge and generated basaltic magmas. Around or above the melt zone, the Middle 
Jurassic I- and S-type magmas formed in the region, such as in Tongshanling ( 164 Ma) in Southern Hunan (Figures 1d and 14b) [19]. The rollback of the Paleo-Pacific plate led to a regional extension during the late Jurassic Era (163-150 Ma) (Figure 14c) [18,19,61,92,93,96]. The extension caused the crust and lithospheric mantle to become thinner, with an accompanying asthenosphere upwelling. The upwelling of the basaltic magmas might have provided heat energy and triggered a partial melting of the thinned crust rocks and subducted sediments to form the ca. 163-150 Ma $\mathrm{A}_{2}$-type granites along the Shi-Hang zone.
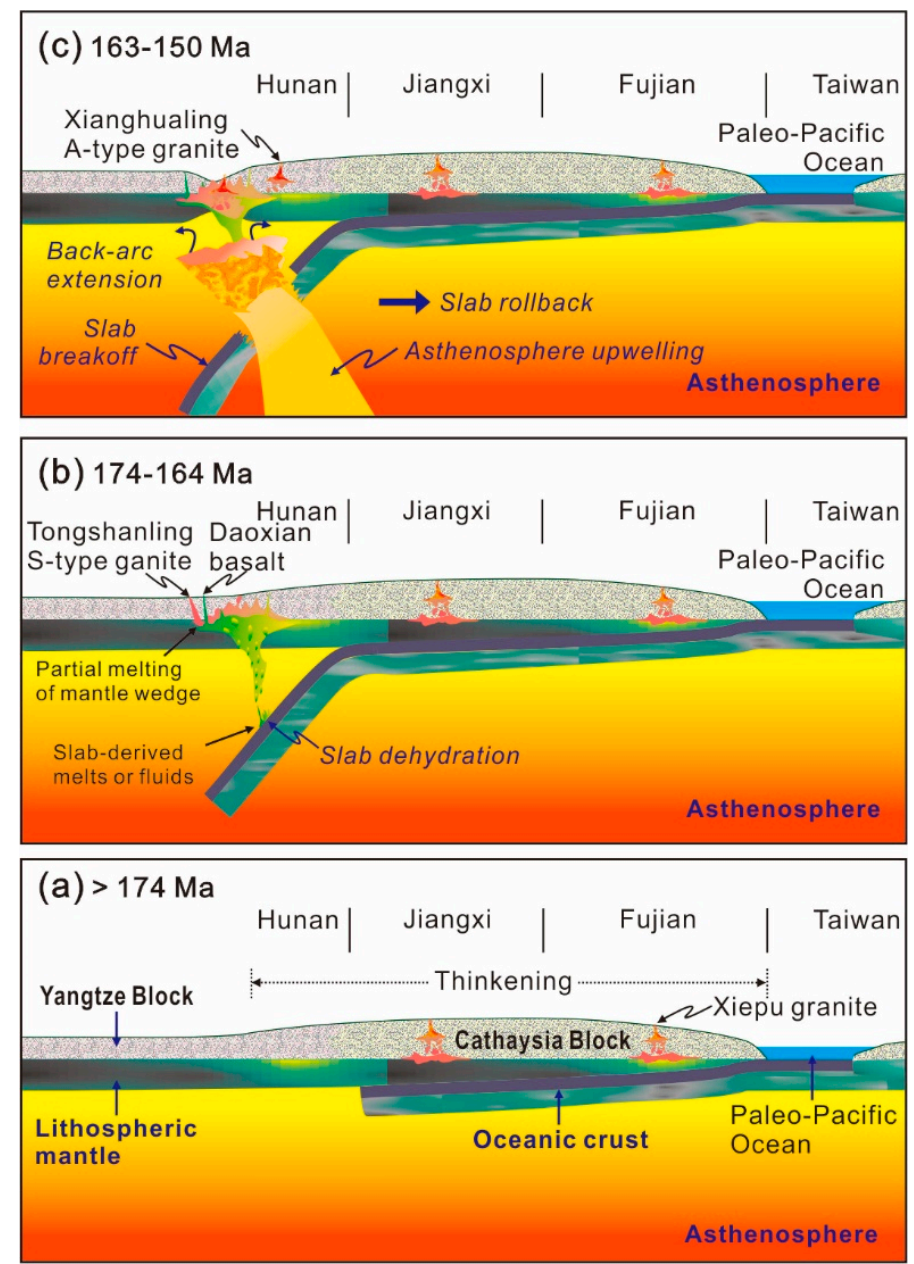

Figure 14. Schematic illustrations showing the generation of the late Jurassic A-type granites in South China. (a) Low angle subduction before $\sim 174 \mathrm{Ma}$, forming the middle Jurassic S-type granites such as the Xiepu granite; (b) High-angle subduction during 174 to $164 \mathrm{Ma}$, forming S-type granites and basalt such as the Tongshanling S-type granite and the Daoxian basalt; (c) During the late Jurassic Era, slab rollback and slab breakoff formed the A-type granite such as the Xianghualing granite.

\subsection{Implication for the Generation of Tin Mineralization}

Yuan et al. [12] gave a cassiterite U-Pb weighted average age of $156 \pm 4 \mathrm{Ma}$. The ore-forming age coincidesdwith the other W-Sn-Pb-Zn deposits in the Shi-Hang zone, such as the Shizhuyuan W deposit (Re-Os, $151 \pm 4$ Ma, [97]; Sm-Nd, $161 \pm 2 \mathrm{Ma}$, [98]; Sm-Nd, $149 \pm 2 \mathrm{Ma}$, [41]), the Furong tin ore field $\left({ }^{40} \mathrm{Ar}-{ }^{39} \mathrm{Ar}, 160-150 \mathrm{Ma},[50]\right)$, the Yaoganxian tungsten deposit (Re-Os, $150 \pm 3 \mathrm{Ma}$, [99]), the Huangshaping $\mathrm{Pb}-\mathrm{Zn}-\mathrm{W}-\mathrm{Sn}-\mathrm{Ag}$ deposit (Re-Os, $155 \pm 2 \mathrm{Ma}$, [38]), the Yuanzhuding Cu-Mo deposit (Re-Os, $157 \pm 4 \mathrm{Ma}$, [47]), and the Xitian W-Sn deposit $\left({ }^{40} \mathrm{Ar}-{ }^{39} \mathrm{Ar}, 157-150 \mathrm{Ma}\right.$ and Cassiterite $\mathrm{U}-\mathrm{Pb}, 154-157 \mathrm{Ma}$ [100-102]). These ages indicate that a globally significant W-Sn polymetallic mineralization has a close relationship with the A-type granites in the Shi-Hang zone. It is further 
supported by the fact that the $\mathrm{Sn}, \mathrm{W}, \mathrm{Pb}$, and $\mathrm{Zn}$ contents of the Mesozoic granites are more than ten times their Clark values, respectively. For examples, the $\mathrm{Sn}, \mathrm{W}, \mathrm{Pb}$, and $\mathrm{Zn}$ contents of the A-type granites in the study area are 8.7-39.7 ppm, 34.4-66.7 ppm, 48.2-66.1 ppm, and 15.0-44.9 ppm, respectively (Table S1). It suggests that they could provide ore-forming materials for mineralization. Moreover, the later Jurassic A-type granites are characterized by high Si (74.1 wt.\% to $78.0 \mathrm{wt} . \%)$ and $\mathrm{Rb}$ (1606 ppm to 2351 ppm) contents, low Ti, P, Sr, and Ba contents, extremely high Rb/Sr ration and flat heavy REE (HREE) with strong negative Eu anomalies. These features imply that an intense fluid-magma interaction is favorable to the formation of the Sn-W-polymetallic mineralization [103, 104]. In the Xianghualing deposit, skarn rocks containing fluorite markedly developed around the granite porphyry, indicating the involvement of an F-rich fluid. The dramatic negative Eu anomaly may indicate that the ore-forming fluids were developed in oxidizing conditions [12]. All of these indicate that there is huge $\mathrm{W}-\mathrm{Sn}$ prospecting potential related to the granites in the Xianghualing deposit.

\section{Conclusions}

(1) The low $\mathrm{Sr}$ and high $\mathrm{Yb} \mathrm{A}$-type granites from the Xianghualing Sn polymetallic deposit were emplaced in the later Jurassic Era ( 153 Ma) with a typical enrichment in $\mathrm{SiO}_{2}$, REEs (except Eu), HFSE, and $\mathrm{Yb}$, and a depletion in $\mathrm{Al}_{2} \mathrm{O}_{3}, \mathrm{CaO}, \mathrm{MgO}$, and $\mathrm{Sr}$.

(2) The geochemical data and isotopic composition ( $\mathrm{Sr}-\mathrm{Nd}-\mathrm{Pb}-\mathrm{Hf})$ suggest that the granites from the Xianghualing deposit were derived from predominantly crustal materials (Mesoproterozoic basement rocks in South China Block and subducted sediments) and some minor subducted sediments.

(3) Crustal partial melting in the extensional tectonic setting was induced by subduction of the Paleo-Pacific Plate, accompanied by the decompression melting in the localized mantle wedge and a rollback of the Paleo-Pacific Plate. These would be the likely accepted combined mechanisms for the petrogenesis of $A_{2}$-type granites.

Supplementary Materials: The following are available online at http:/ / www.mdpi.com/2075-163X/9/3/182/s1, Table S1: Whole-rock major and trace element of the low-Sr and high-Yb granites in the Xianghualing, SW China; Table S2: Sr, Nd and Pb isotope data for selected granites from Xiahualing, South China. Table S3: LA-ICP-MS zircon $\mathrm{U}-\mathrm{Pb}$ age data of the late Jurassic low-Sr and high- $\mathrm{Yb}$ A-type granites from Xianghualing, South China; Table S4: In situ zircon Hf isotope data for the later Jurassic low-Sr and high-Yb A-type granites in the Xianghualing Sn-polymetallic deposit, South China.

Author Contributions: Conceptualization, C.H.X. and C.S.W.; Data curation, C.H.X. and Y.K.S.; Investigation, C.H.X. and C.S.W.; Project administration, Y.K.S.; Writing—original draft, C.H.X.; Writing—review \& editing, C.H.X.

Funding: This research was jointly funded by the National Key R\&D Program of China (No. 2016YFC0600107) and the Basic Research Fund of the Chinese Academy of Geological Sciences (No. JYYWF20180602, JYYWF20183702).

Acknowledgments: We would like to thank Qing Zhang, Kun-Feng Qiu, and two anonymous reviewers for the constructive comments and suggestions on this paper.

Conflicts of Interest: The authors declare no conflict of interest.

\section{References}

1. Li, X.H.; McCulloch, M.T. Nd isotopic evolution of sediments from the southern margin of the Yangtze Block and its tectonic significance. Acta Petrol. Sin. 1996, 12, 359-369. (In Chinese with English abstract)

2. Metcalfe, I. Palaeozoic and Mesozoic tectonic evolution and palaeogeography of East Asian crustal fragments: The Korean Peninsula in context. Gondwana Res. 2006, 9, 24-46. [CrossRef]

3. Metcalfe, I. Tectonic framework and Phanerozoic evolution of Sundaland. Gondwana Res. 2011, $19,3-21$. [CrossRef]

4. Zheng, Y.F.; Xiao, W.J.; Zhao, G.C. Introduction to tectonics of China. Gondwana Res. 2013, 23, 1189-1206. [CrossRef] 
5. Gilder, S.A.; Gill, J.; Coe, R.S.; Zhao, X.; Liu, Z.; Wang, G.; Yuan, K.; Liu, W.; Kuang, G.; Wu, H. Isotopic and paleomagnetic constraints on the Mesozoic tectonic evolution of South China. J. Geophys. Res. 1996, 101, 16137-16154. [CrossRef]

6. Mao, J.W.; Li, X.F.; Chen, W.; Lan, X.M.; Wei, S.L. Geological characteristics of the Furong tin orefield, Hunan, ${ }^{40} \mathrm{Ar}-{ }^{39} \mathrm{Ar}$ dating of tin ores and related granite and its geodynamic significance for rock and ore formation. Acta Geol. Sin. (Engl. Ed.) 2004, 78, 481-491.

7. Ding, T.; Ma, D.S.; Lu, J.J.; Zhang, R.Q.; Zhang, S.T. S, Pb and Sr isotope geochemistry and genesis of $\mathrm{Pb}-\mathrm{Zn}$ mineralization in the Huangshaping polymetallic ore deposit of southern Hunan Province, China. Ore Geol. Rev. 2016, 77, 117-132. [CrossRef]

8. Hu, R.Z.; Mao, J.W.; Fan, W.M.; Hua, R.M.; Bi, X.W.; Zhong, H.; Song, X.Y.; Tao, Y. Some scientific questions on the intra-continental metallogeny in the South China continent. Earth Sci. Front. 2010, 17, 13-26. (In Chinese)

9. Hua, R.M.; Chen, P.R.; Zhang, W.L.; Liu, X.D.; Lu, J.J.; Lin, J.F.; Yao, J.M.; Qi, H.W.; Zhang, Z.S.; Gu, S.Y. Metallogenic systems related to Mesozoic and Cenozoic granitoids in South China. Sci. China D 2003, 46, 816-829. [CrossRef]

10. Pirajno, F.; Bagas, L. Gold and silver metallogeny of the South China Fold Belt: A consequence of multiple mineralizing events? Ore Geol. Rev. 2002, 20, 109-126. [CrossRef]

11. Shu, X.J.; Wang, X.L.; Sun, T.; Xu, X.S.; Dai, M.N. Trace elements, U-Pb ages and Hf isotopes of zircons from Mesozoic granites in the western Nanling range, South China: Implications for petrogenesis and W-Sn mineralization. Lithos 2011, 127, 468-482. [CrossRef]

12. Yuan, S.D.; Peng, J.T.; Hu, R.Z.; Li, H.M.; Shen, N.P.; Zhang, D.L. A precise U-Pb age on cassiterite from the Xianghualing tin-polymetallic deposit (Hunan, South China). Miner. Depos. 2008, 43, 375-382. [CrossRef]

13. Zaw, K.; Peters, S.G.; Cromie, P.; Burrett, C.; Hou, Z. Nature, diversity of deposit types and metallogenic relations of South China. Ore Geol. Rev. 2007, 31, 3-47. [CrossRef]

14. Zhong, L.F.; Li, J.; Peng, T.P.; Xia, B.; Liu, L.W. Zircon U-Pb geochronology and Sr-Nd-Hf isotopic compositions of the Yuanzhuding granitoid porphyry within the Shi-Hang Zone, South China: Petrogenesis and implications for Cu-Mo mineralization. Lithos 2013, 177, 402-415. [CrossRef]

15. Zhou, Y.; Liang, X.Q.; Wu, S.C.; Cai, Y.F.; Liang, X.R.; Shao, T.B.; Wang, C.; Fu, J.G.; Jiang, Y. Isotopic geochemistry, zircon $\mathrm{U}-\mathrm{Pb}$ ages and $\mathrm{Hf}$ isotopes of A-type granites from the Xitian $\mathrm{W}-\mathrm{Sn}$ deposit, SE China: Constraints on petrogenesis and tectonic significance. J. Asian Earth Sci. 2015, 105, 122-139. [CrossRef]

16. Gilder, S.A.; Keller, G.R.; Luo, M.; Goodell, P.C. Timing and spatial distribution of rifting in China. Tectonophysics 1991, 197, 225-243. [CrossRef]

17. Li, X.H. Cretaceous magmatism and lithospheric extension in Southeast China. J. Asian Earth Sci. 2000, 18, 293-305. [CrossRef]

18. Jiang, Y.H.; Ling, H.F.; Jiang, S.Y.; Fan, H.H.; Shen, W.Z.; Ni, P. Petrogenesis of a Late Jurassic peraluminous volcanic complex and its high-Mg, potassic, quenched enclaves at Xiangshan, Southeast China. J. Petrol. 2005, 46, 1121-1154. [CrossRef]

19. Jiang, Y.H.; Jiang, S.Y.; Dai, B.Z.; Liao, S.Y.; Zhao, K.D.; Ling, H.F. Middle to late Jurassic felsic and mafic magmatism in southern Hunan province, southeast China: Implications for a continental arc to rifting. Lithos 2009, 107, 185-204. [CrossRef]

20. Chen, J.F.; Jahn, B.M. Crustal evolution of southeastern China: Nd and Sr isotopic evidence. Tectonophysics 1998, 284, 101-133. [CrossRef]

21. Zhou, X.M.; Sun, T.; Shen, W.Z.; Shu, L.S.; Niu, Y.L. Petrogenesis of Mesozoic granitoids and volcanic rocks in South China: A response to tectonic evolution. Episodes 2006, 29, 26-33.

22. Zhu, K.Y.; Li, Z.X.; Xu, X.S.; Wilde, S.A. Late Triassic melting of a thickened crust in southeastern China: Evidence for flat-slab subduction of the Paleo-Pacific plate. J. Asian Earth Sci. 2013, 74, 265-279. [CrossRef]

23. Zhu, K.Y.; Li, Z.X.; Xu, X.S.; Wilde, S.A. A Mesozoic Andean-type orogenic cycle in southeastern China as recorded by granitoid evolution. Am. J. Sci. 2014, 314, 187-234. [CrossRef]

24. Zhu, K.Y.; Li, Z.X.; Xu, X.S.; Wilde, S.A.; Chen, H.L. Early Mesozoic ferroan (A-type) and magnesian granitoids in eastern South China: Tracing the influence of flat-slab subduction at the western Pacific margin. Lithos 2016, 240, 371-381. [CrossRef]

25. Wang, Y.J.; Fan, W.M.; Cawood, P.A.; Li, S.Z. Sr-Nd-Pb isotopic constraints on multiple mantle domains for Mesozoic mafic rocks beneath the South China Block hinterland. Lithos 2008, 106, 297-308. [CrossRef] 
26. Li, X.H.; Li, Z.X.; Li, W.X.; Wang, X.C.; Gao, Y. Revisiting the "C-type adakites" of the Lower Yangtze River Belt, central eastern China: In-situ zircon Hf-O isotope and geochemical constraints. Chem. Geol. 2013, 345, 1-15. [CrossRef]

27. Mao, J.W.; Cheng, Y.B.; Chen, M.H.; Pirajno, F. Major types and time-space distribution of Mesozoic ore deposits in South China and their geodynamic settings. Lithos 2013, 48, 267-294.

28. Zhou, X.M.; Li, W.X. Origin of late Mesozoic igneous rocks in southeastern China: Implications for lithosphere subduction and underplating of mafic magmas. Tectonophysics 2000, 326, 269-287. [CrossRef]

29. Zhu, J.C.; Xie, C.F.; Zhang, P.H.; Yang, C.; Gu, C.Y. Niemiao and Tong'an intrusive bodies of NE Guangxi: Petrology, zircon SHRIMP U-Pb geochronology and geochemistry. Acta Petrol. Sin. 2005, 21, 665-676. (In Chinese)

30. Zhu, J.C.; Zhang, P.H.; Xie, C.F.; Zhang, H.; Yang, C. The Huashan-Guposhan A type granitoid belt in the western part of the Nanling Mountains: Petrology, geochemistry and genetic interpretations. Acta Geol. Sin. 2006, 80, 529-542. (In Chinese)

31. Zhu, J.C.; Zhang, P.H.; Xie, C.F.; Zhang, H.; Yang, C. Magma mixing origin of the mafic enclaves in Lisong Granite, NE Guangxi, western Nanling Mountains. Geochimica 2006, 35, 506-516. (In Chinese)

32. Wang, Y.J.; Fan, W.M.; Guo, F. Geochemistry of early Mesozoic potassium-rich diorites-granodiorites in southeastern Hunan Province, South China: Petrogenesis and tectonic implications. Geochem. J. 2003, 37, 427-448. [CrossRef]

33. Fu, J.M.; Ma, C.Q.; Xie, C.F.; Zhang, Y.M.; Peng, S.B. Shrimp U-Pb zircon dating of the Jiuyishan composite granite in Hunan and its geological significance. Geotecton. Metallog. 2004, 28, 370-378. (In Chinese)

34. Ma, T.Q.; Bai, D.Y.; Kuang, J.; Peng, X.J.; Wang, X.H. ${ }^{40} \mathrm{Ar}-{ }^{39} \mathrm{Ar}$ dating and geochemical characteristics of the granites in north Dadongshan pluton, Nangling Mountains. Geochimica 2006, 35, 333-345.

35. Li, X.H.; Chung, S.L.; Zhou, H.W.; Lo, C.H.; Liu, Y.; Chen, C.H. Jurassic intraplate magmatism in southern Hunan-eastern Guangxi: 40Ar/39Ar dating geochemistry, Sr-Nd isotopes and implications for the tectonic evolution of SE China. Geol. Soc. Lond. Spec. Publ. 2004, 226, 193-215. [CrossRef]

36. Zhao, G.D.; Jiang, S.Y.; Liu, D.Y. SHRIMP U-Pb dating of the Furong unit of Qitangling granite from southeast Hunan province and their geological implications. Acta Petrol. Sin. 2006, 22, 2611-2616.

37. Li, H.; Koichiro, W.; Kotaro, Y. Geochemistry of A-type granites in the Huangshaping polymetallic deposit (South Hunan, China): Implications for granite evolution and associated mineralization. J. Asian Earth Sci. 2014, 88, 149-167. [CrossRef]

38. Lu, Y.F.; Ma, L.Y.; Qu, W.J.; Mei, Y.P.; Chen, X.Q. U-Pb and Re-Os isotope geochronology of Baoshan Cu-Mo polymetallic ore deposit in Hunan Province. Acta Petrol. Sin. 2006, 22, 2483-2492. (In Chinese)

39. Li, X.H. Geochronology of Wanyangshan-Zhuguangshan granitoid batholith: Implication for the crust development. Sci. China (Ser. B) 1991, 34, 620-629.

40. Yin, Z.P.; Ling, H.F.; Huang, G.R.; Shen, W.Z.; Wang, L. Research on geochemical characteristics and genesis of Jiufeng rock mass in Northern Guangdong Province. J. East China Inst. Technol. 2010, 33, 15-21. (In Chinese)

41. Li, X.H.; Liu, D.Y.; Sun, M.; Li, W.X.; Liang, X.R.; Liu, Y. Precise Sm-Nd and U-Pb isotopic dating of the supergiant Shizhuyuan polymetallic deposit and its host granite, SE China. Geol. Mag. 2004, 141, 225-231. [CrossRef]

42. Li, C.F.; Li, X.H.; Guo, J.F.; Li, X.F.; Li, H.K.; Zhou, H.Y.; Li, Z.G. Single-step separation of Rb-Sr and Pb from minor rock samples and high precision determination using thermal ionization mass spectrometry. Geochimica 2011, 40, 399-406. (In Chinese)

43. Lv, K.; Wang, Y.; Xiao, J. Geochemistry characteristics of Xihuashan granite and structural environment discussion. J. East China Inst. Technol. 2011, 34, 117-128. (In Chinese)

44. Shen, W.Z.; Xu, S.J.; Wang, Y.X.; Yang, J.D. Research of the Nd-Sr isotopic composition of Xihuashan granite. Chin. Sci. Bulltin 1994, 39, 154-156. (In Chinese)

45. Jiang, Y.H.; Zhao, P.; Zhou, Q.; Liao, S.Y.; Jin, G.D. Petrogenesis and tectonic implications of Early Cretaceous S- and A-type granites in the northwest of the Gan-Hang rift, SE China. Lithos 2011, 121, 57-73. [CrossRef]

46. Zhou, Q.; Jiang, Y.H.; Liao, S.Y.; Zhao, P.; Jin, G.D.; Jia, R.Y.; Liu, Z.; Xu, S.M. SHRIMP zircon U-Pb dating and Hf isotope studies of the diorite porphyrite from the Dexing copper deposit. Acta Geol. Sin. 2012, 86, 1726-1734.

47. Zhong, L.F.; Liu, L.W.; Xia, B.; Li, J.; Lin, X.G.; Xu, L.F.; Lin, L.Z. Re-Os geochronology of molybdenite from Yuanzhuding porphyry Cu-Mo deposit in South China. Resour. Geol. 2010, 60, 389-396. [CrossRef] 
48. Lu, H.Z.; Liu, Y.M.; Wang, C.L.; Xu, Y.Z.; Li, H.Q. Mineralization and fluid inclusion study of the Shizhuyuan W-Sn-Bi-Mo-F skarn deposit, Hunan Province, China. Econ. Geol. 2003, 98, 955-974. [CrossRef]

49. Li, Z.L.; Hu, R.Z.; Peng, J.T.; Bi, X.W.; Li, X.M. Helium isotopic geochemistry of ore-forming fluids tin deposit in Hunan Province, China. Resour. Geol. 2006, 56, 9-16. [CrossRef]

50. Peng, J.T.; Hu, R.Z.; Bi, X.W.; Dai, T.M.; Li, Z.L.; Li, X.M.; Shuang, Y.; Yuan, S.D.; Liu, S.R. 40Ar/39Ar isotopic dating of tin mineralization in Furong deposit, Hunan and its geological significance. Miner. Depos. 2007, 26, 237-248. (In Chinese)

51. Yuan, S.D.; Peng, J.T.; Shen, N.P.; Hu, R.Z.; Dai, T.M. 40Ar-39Ar isotopic dating of the Xianghualing, Hunan, Sn-polymetallic orefield and its geological implications. Acta Geol. Sin. (Engl. Ed.) 2007, 81, 278-286.

52. Yao, J.M.; Hua, R.M.; Du, A.D.; Qi, H.W. Re-Os isotopic dating of the molybdenite from Huangshaping $\mathrm{Pb}-\mathrm{Zn}$ deposit in Southern Hunan and its implications. Sci. China (Ser. D) 2007, 37, 471-477. (In Chinese)

53. Xuan, Y.S.; Yuan, S.D.; Yuan, Y.B.; Mi, J.R. Zircon U-Pb age, geochemistry and Petrogenesis of Jianfengling pluton in southern Hunan Province. Miner. Depos. 2014, 33, 1379-1390.

54. Bai, D.Y.; Chen, J.C.; Ma, T.Q.; Wang, X.H. Geochemical characteristics and tectonic setting of Qitianling A-type granitic Pluton in southeast Hunan. Acta Petrol. Et Mineral. 2005, 24, 255-272. (In Chinese with English abstract)

55. Li, Z.L.; Hu, R.Z.; Yang, J.S.; Peng, J.T.; Li, X.M.; Bi, X.W. He, Pb and S isotopic constraints on the relationship between the A-type Qitianling granite and the Furong tin deposit, Hunan Province, China. Lithos 2007, 97, 161-173. [CrossRef]

56. Frost, B.R.; Brans, C.G.; Collins, W.J.; Arculus, R.J.; Ellis, D.J.; Frost, C.D. Geochemical classification for granitic rocks. J. Petrol. 2001, 42, 2033-2048. [CrossRef]

57. Maniar, P.D.; Piccoli, P.M. Tectonic discrimination of granitoids. Geol. Soc. Am. Bull. 1989, 101, 635-643. [CrossRef]

58. Sun, S.S.; McDonough, W. Chemical and isotopic systematics of oceanic basalts: Implications for mantle composition and processes. Geol. Soc. Lond. Spec. Publ. 1989, 42, 313-345. [CrossRef]

59. Whalen, J.B.; Currie, K.L.; Chappell, B.W. A-type granites: Geochemical characteristics, discrimination and petrogenesis. Contrib. Mineral. Petrol. 1987, 95, 407-419. [CrossRef]

60. Wu, S.P.; Wu, C.L.; Chen, Q.L.; Zhang, C.Q.; Li, D.S. Error estimation of initial ratios of Sr-Nd isotope and Nd model age. Acta Geol. Sin. 2009, 83, 1031-1038. (In Chinese)

61. Wong, J.; Sun, M.; Xing, G.F.; Li, X.H.; Zhao, G.C.; Wong, K.; Yuan, C.; Xia, X.P.; Li, L.M.; Wu, F.Y. Geochemical and zircon $\mathrm{U}-\mathrm{Pb}$ and $\mathrm{Hf}$ isotopic study of the Baijuhuajian metaluminous A-type granite: Extension at 125-100 Ma and its tectonic significance for South China. Lithos 2009, 112, 289-305. [CrossRef]

62. Hoskin, P.W.O.; Schaltegger, U. The composition of zircon and igneous and metamorphic petrogenesis. Rev. Mineral. Geochem. 2003, 53, 27-55. [CrossRef]

63. Douce, A.E.P. Generation of metaluminous A-type granites by low-pressure melting of calc-alkaline granitoids. Geology 1997, 25, 743-746. [CrossRef]

64. Eby, G.N.; Kochhar, N. Geochemistry and petrogenesis of the Malani igneous suite, North Peninsular India. J. Geol. Soc. India 1990, 36, 109-130.

65. Loiselle, M.C.; Wones, D.R. Characteristics and origin of anorogenic granites. Geol. Soc. Am. Abstr. Programs 1979, 11, 468.

66. Shen, X.M.; Zhang, H.X.; Wang, Q.; Wymanc, D.A.; Yang, Y.H. Late Devonian-Early Permian A-type granites in the southern Altay Range, Northwest China: Petrogenesis and implications for tectonic setting of “A2-type" granites. J. Asian Earth Sci. 2011, 42, 986-1007. [CrossRef]

67. Zhang, Q.; Li, C.D.; Wang, Y.; Wang, Y.L.; Jin, W.J.; Jia, X.Q.; Han, S. Mesozoic high-Sr and Low-Yb granitoids and low-Sr and high-Yb granitoids in eastern China: Comparison and geological implications. Acta Petrol. Sin. 2005, 21, 1527-1537.

68. Williams, I.S. Some observations on the use of zircon U-Pb geochronology in the study of granitic-rocks. Earth Environ. Sci. Trans. R. Soc. Edinb. 1987, 83, 447-458. [CrossRef]

69. de la Roche, H.; Leterrier, J.; Grand Claude, P. and Marchal, M. A classification of volcanic and plutonic rocks using R1-R2 diagrams and major element analyses-Its relationships with current nomenclature. Chem. Geol. 1980, 29, 183-210. [CrossRef]

70. Eby, G.N. Chemical subdivision of the A-type granitoids: Petrogenetic and tectonic implication. Geology 1992, 20, 641-644. [CrossRef] 
71. Bonin, B. A-type granites and related rocks: Evolution of a concept, problems and prospects. Lithos 2007, 97, 1-29. [CrossRef]

72. King, P.L.; White, A.J.R.; Chappell, B.W.; Allen, C.M. Characterization and origin of aluminous A-type granites from the Lachlan Fold Belt, Southeastern Australia. J. Petrol. 1997, 38, 371-391. [CrossRef]

73. Zhang, Q.; Wang, Y.; Li, C.D.; Wang, Y.L.; Jin, W.J.; Jia, X.Q. Granite classification on the basis of Sr and Yb contents and its implications. Acta Petrol. Sin. 2006, 22, 2249-2269. (In Chinese)

74. Clemens, J.D.; Holloway, J.R.; White, A.J.R. White Origin of an A-type granite; experimental constraints. Am. Mineral. 1986, 71, 317-324.

75. Collins, W.J.; Beams, S.D.; White, A.J.R.; Chappell, B.W. Nature and origin of A-type granites with particular reference to southeastern Australia. Contrib. Mineral. Petrol. 1982, 80, 189-200. [CrossRef]

76. Chappell, B.W. Granitoids from the Moonbi district, New England Batholith, Eastern Australia. J. Geol. Soc. Aust. 1987, 25, 267-283. [CrossRef]

77. Creaser, R.A.; Price, R.C.; Wormald, R.J. A-type granites revisited: Assessment of a residual-source model. Geology 1991, 19, 163-166. [CrossRef]

78. Gaudemer, Y.; Jaupart, C.; Tapponnier, P. Thermal control on post-orogenic extension in collision belts. Earth Planet. Sci. Lett. 1988, 89, 48-62. [CrossRef]

79. Patiño Dounce, A.E.; Beard, J.S. Dehydration-melting of biotite gneiss and quartze amphibolite from 3 to 15 kbar. J. Petrol. 1995, 36, 707-738. [CrossRef]

80. Li, H.Y.; Mao, J.W.; Sun, Y.L.; Du, A.D. Re-Os isotopic chronology of molybdenites in the Shizhuyuan polymetallic tungsten deposit. Geol. Rev. 1996, 42, 261-267. (In Chinese with English abstract)

81. Mao, J.W.; Li, H.Y.; Pei, R. Nd-Sr isotopic and petrogenetic studies of the Qianlishan granite stock. Hunan Province. Miner. Depos. 1995, 14, 235-242. (In Chinese with English abstract)

82. Zhu, J.C.; Li, X.D.; Shen, W.Z.; Wang, Y.X.; Yang, J.D. Sr, Nd and O isotope studies on the genesis of the Huashan granite complex. Acta Geol. Sin. 1989, 3, 225-235. (In Chinese with English abstract)

83. Zartman, R.E.; Haines, S.M. The plumbotectonic model for Pb isotopic systematics among major terrestrial reservoirs-A case for bi-directional transport. Geochim. Cosmochim. Acta 1988, 52, 1327-1339. [CrossRef]

84. Dall'Agnol, R.; Scaillet, B.; Pichavant, M. An experimental study of a Lower Proterozoic A-type granite from the Eastern Amazonian Craton, Brazil. J. Petrol. 1999, 40, 1673-1698. [CrossRef]

85. Rajesh, H.M. Characterization and origin of a compositionally zoned aluminous A-type granite from South India. Geol. Mag. 2000, 137, 291-318. [CrossRef]

86. Wu, F.Y.; Sun, D.Y.; Li, H.; Jahn, B.M.; Wilde, S. A-type granites in northeastern China: Age and geochemical constraints on their petrogenesis. Chem. Geol. 2002, 187, 143-173. [CrossRef]

87. Dai, B.Z.; Jiang, S.Y.; Jiang, Y.H.; Zhao, K.D.; Liu, D.Y. Geochronology, geochemistry and Hf-Sr-Nd isotopic compositions of Huziyan mafic xenoliths, southern Hunan Province, South China: Petrogenesis and implications for lower crust evolution. Lithos 2008, 102, 65-87. [CrossRef]

88. Zhao, Z.H.; Bao, Z.W.; Zhang, B.Y.; Xiong, X.L. Crust-mantle interaction and its contribution to the Shizhuyuan tungsten-polymetallic mineralization. Sci. China (Ser. D) Earth Sci. 2001, 44, 266-276. [CrossRef]

89. Ye, H.M.; Mao, J.R.; Zhao, X.L.; Liu, K.; Chen, D.D. Revisiting Early-Middle Jurassic igneous activity in the Nanling Mountains, South China: Geochemistry and implications for regional geodynamics. J. Asian Earth Sci. 2013, 72, 108-117. [CrossRef]

90. Lapierre, H.; Jahn, B.M.; Charvet, J.; Yu, Y.W. Mesozoic felsic arc magmatism and continental olivine tholeiites in Zhejiang province and their relationship with the tectonic activity in southeastern China. Tectonophysics 1997, 274, 321-338. [CrossRef]

91. Li, Z.X.; Li, X.H. Formation of the $1300-\mathrm{km}-$ wide intracontinental orogen and postorogenic magmatic province in Mesozoic South China: A flat-slab subduction model. Geology 2007, 35, 179-182. [CrossRef]

92. Jiang, S.Y.; Zhao, K.D.; Jiang, Y.H.; Dai, B.Z. Characteristics and genesis of Mesozoic A-type granites and associated mineral deposits in the southern Hunan and northern Guangxi provinces along the Shi-Hang belt, South China. Geol. J. China Univ. 2008, 14, 496-509. (In Chinese with English abstract)

93. Jiang, Y.H.; Wang, G.C.; Liu, Z.; Ni, C.Y.; Qing, L.; Zhang, Q. Repeated slab-advanceretreat of the Palaeo-Pacific plate underneath SE China. Int. Geol. Rev. 2015, 57, 472-491. [CrossRef]

94. Wang, G.C.; Jiang, Y.H.; Liu, Z.; Ni, C.Y.; Qing, L.; Zhang, Q.; Zhu, S.Q. Multiple origins for the Middle Jurassic to Early Cretaceous high-K calc-alkaline I-type granites in northwestern Fujian province, SE, China and tectonic implications. Lithos 2016, 246-247, 197-211. [CrossRef] 
95. Tatsumi, Y.; Eggins, S. Subduction Zone Magmatism; Blackwell Science: New York, NY, USA, 1995; pp. 1-211.

96. Sun, F.; Xu, X.; Zou, H.; Xia, Y. Petrogenesis and magmatic evolution of $130 \mathrm{Ma}$ A-type granites in Southeast China. J. Asian Earth Sci. 2015, 98, 209-224. [CrossRef]

97. Li, X.H.; McCulloch, M.T. Secular variation in the Nd isotopic composition of Neoproterozoic sediments from the southern margin of the Yangtze Block: Evidence for a Proterozoic continental collision in southeast China. Precambrian Res. 1996, 76, 67-76. [CrossRef]

98. Liu, Y.M.; Dai, T.M.; Lu, H.Z.; Xu, Y.Z.; Wang, C.L.; Kang, W.Q. Isotopic data of 40Ar/39Ar and Sm-Nd for diagenesis-metallogenesis of the Qianlishan granite. Sci. China (Ser. D) 1997, 27, 425-430. (In Chinese)

99. Peng, J.T.; Zhou, M.F.; Hu, R.Z.; Shen, N.P.; Yuan, S.D.; Bi, X.W.; Du, A.D.; Qu, W.J. Precise molybdenite Re-Os and mica Ar-Ar dating of the Mesozoic Yaogangxian tungsten deposit, central Nanling district, South China. Miner. Depos. 2006, 41, 661-669. [CrossRef]

100. Fu, J.M.; Cheng, S.B.; Lu, Y.Y.; Wu, S.C.; Ma, L.Y.; Chen, X.Q. Geochronology of the greisen-quartz-vein type tungsten-tin deposit and its host granite in Xitian, Hunan Province. Geol. Explor. 2012, 48, 0313-0320. (In Chinese with English abstract)

101. Liu, Y.S.; Hu, Z.C.; Gao, S.; Günther, D.; Xu, J.; Gao, C.G.; Chen, H.H. In situ analysis of major and trace elements of anhydrous minerals by LA-ICP-MS without applying an internal standard. Chem. Geol. 2008, 257, 34-43. [CrossRef]

102. Jiang, W.C.; Li, H.; Wu, J.H.; Zhou, Z.K.; Kong, H.; Cao, J.Y. A newly Found Biotite Syenogranite in the Huangshaping Polymetallic Deposit, South China: Insights into Cu Mineralization. J. Earth Sci. 2018, 29, 537-555. [CrossRef]

103. Ma, L.Y.; Fu, J.M.; Wu, S.C.; Xu, D.M.; Yang, X.J. 40Ar/39Ar isotopic dating of the Longshang tin-polymetallic deposit, Xitian orefield, eastern Hunan. Geol. China 2008, 35, 706-713. (In Chinese with English abstract)

104. Bastos Neto, A.C.; Pereira, V.P.; Ronchi, L.H.; DeLima, E.F.; Frantz, J.C. The world-class Sn, Nb, Ta, F (Y, REE, $\mathrm{Li})$ deposit and the massive cryolite associated with the albite-enriched facies of the Madeira A-type granite, Pitinga mining district, Amazonas state, Brazil. Can. Mineral. 2009, 47, 1329-1357. [CrossRef]

(C) 2019 by the authors. Licensee MDPI, Basel, Switzerland. This article is an open access article distributed under the terms and conditions of the Creative Commons Attribution (CC BY) license (http:/ / creativecommons.org/licenses/by/4.0/). 